\title{
Tectonic activity and structural features of active intracontinental normal faults in the Weihe Graben, central China
}

\section{AUTHOR(S):}

Rao, Gang; Lin, Aiming; Yan, Bing; Jia, Dong; Wu, Xiaojun

\section{CITATION:}

Rao, Gang ... [et al]. Tectonic activity and structural features of active intracontinental normal faults in the Weihe Graben, central China. Tectonophysics 2014, 636: 270-285

\section{ISSUE DATE:}

2014-12

URL:

http://hdl.handle.net/2433/191107

\section{RIGHT:}

(C) 2014 Elsevier B.V.; This is not the published version. Please cite only the published version.; この論文は出版社版でありません。引用の際に は出版社版をご確認ご利用ください。 
Highlights

- We studied the active normal faults in the intracontinental Weihe Graben, China.

Active faults are characterized by stepwise fault scarps with dip-angles of $40^{\circ}-71^{\circ}$.

Active normal fault scarps are distributed in a wide zone of up to $500 \mathrm{~m}$.

- Structural and topographic features indicate a pure dip-slip sense of the fault zone.

Average dip-slip rate is estimated to be $\sim 3.0-4.0 \mathrm{~mm} / \mathrm{yr}$ for the normal fault zone. 
Tectonic activity and structural features of active intracontinental normal faults in the Weihe Graben, central

\title{
China
}

Gang Rao ${ }^{1,2 \#}$, Aiming Lin ${ }^{1 *}$, Bing Yan ${ }^{1,2}$, Zhikun Ren $^{3}$, Dong Jia ${ }^{4}$, and Xiaojun Wu ${ }^{4}$ ${ }^{1}$ Department of Geophysics, Graduate School of Science, Kyoto University Kyoto 606-8502, Japan

${ }^{2}$ Graduate School of Science and Technology, Shizuoka University Shizuoka 422-8529, Japan

${ }^{3}$ State Key Laboratory of Earthquake Dynamics, Institute of Geology, China Earthquake Administration, Beijing 100029, China

${ }^{4}$ Department of Earth Sciences, Nanjing University Nanjing 210093, China

\#Current address: Department of Earth Sciences, Zhejiang University Hangzhou 310027, China

\author{
$* * * * * * * * * * * * * * * * * * * * * * * * * * * * * * * * * * * * *$ \\ *Corresponding author: \\ Department of Geophysics \\ Graduate School of Science, Kyoto University \\ Kyoto 606-8502, Japan \\ Tel: 81-75-753-3941 \\ E-mail: slin@kugi.kyoto-u.ac.jp (A. Lin)
}

\section{Abstract}


This study examines the tectonic activity and structural features of active normal faults in the Weihe Graben, central China. The Weihe Graben is an area with a high level of historic seismicity, and it is one of the intracontinental systems that developed since Tertiary in the extensional environment around the Ordos Block. Analysis of high-resolution remote-sensing imagery data, field observations, and radiocarbon dating results reveal the following: i) active normal faults are mainly developed within a zone $<500 \mathrm{~m}$ wide along the southern border of the eastern part of the Weihe Graben; ii) the active faults that have been identified are characterized by stepwise fault scarps dipping into the graben at angles of $40^{\circ}-71^{\circ}$; iii) there are numerous discontinuous individual fault traces, ranging in length from a few tens of meters to $450 \mathrm{~m}$ (generally $<200 \mathrm{~m}$ ); iv) fault zone structures, topographic features, and fault striations on the main fault planes indicate almost pure normal-slip; and v) late Pleistocene-Holocene terrace risers, loess, and alluvial deposits have been vertically offset by up to $\sim 80 \mathrm{~m}$, with an average dip-slip rate (throw-rate) of $\sim 3.0-4.0 \mathrm{~mm} / \mathrm{yr}$. Our results reveal that active normal faults have been developing in the Weihe Graben under an ongoing extensional environment, probably associated with the pre-existing graben and spreading of the continental crust, and this is in contrast with the Ordos Block and neighboring orogenic regions. These results provide new insights into the nature of extensional tectonic deformation in intracontinental graben systems.

Keywords: active intracontinental normal fault, fault scarp, tectonic activity, Weihe Graben, Ordos Block 


\section{Introduction}

The Tibetan Plateau has been uplifted due to the ongoing collision between the Indian and Eurasia plates since the Early Eocene (e.g., Harrison et al., 1992; Yin and Harrison, 2000). The plateau and neighboring regions in East Asia are ideal places for studying active tectonics, because the orogeny is still active and the collision has produced a variety of geological features including large-scale thrust, normal, and strike-slip fault systems (e.g., Tapponnier and Molnar, 1977; Molnar and Deng, 1984; Armijo et al., 1986; Molnar and Lyon-Caen, 1989; Liu et al., 2004). The co-seismic rupture structures associated with thrusting and strike-slip movements, in and around the Tibetan Plateau (Fig. 1), have been well investigated on the basis of numerous large earthquakes, including the $2008 \mathrm{M}_{\mathrm{w}} 7.9$ Wenchuan earthquake due to thrusting (e.g., Lin et al., 2009; Jia et al., 2010; Li et al., 2010), the $2001 \mathrm{M}_{\mathrm{w}} 7.8$ Kunlun earthquake due to strike-slip movement (e.g., Lin et al., 2002), and the $2010 \mathrm{M}_{\mathrm{w}} 6.9$ Yushu earthquake, also due to strike-slip movement (e.g., Lin et al., 2011; Rao et al., 2011; Guo et al., 2012). In contrast, we have relatively less understanding of the tectonic geomorphology and structural features related to active intracontinental normal faults, or the co-seismic rupturing mechanisms of such faults (e.g., Armijo et al., 1986; Sun et al., 2011). Although previous studies have reported some structural features of co-seismic surface ruptures associated with normal faulting locally such as western USA (e.g., Myers and Hamilton, 1964; Wallace, 1984; Crone et al., 1987), large earthquakes caused by normal faulting are still rare worldwide in contrast with the thrust-type and strike-slip earthquakes. Recently, the $2011 \mathrm{M}_{\mathrm{w}} 6.6$ Fukushima 
earthquake, one of the aftershocks triggered by the $2011 \mathrm{M}_{\mathrm{w}} 9.0$ Tohoku earthquake in Japan, generated a $\sim 23-\mathrm{km}$-long surface rupture zone along the pre-existing active normal faults developed in the intracontinental rift environment characterized by thick half-graben sediments as that of the Weihe Graben, the target of this study, which provides a typical example of large earthquake triggered by normal faulting (e.g., Lin et al., 2013a; Toda and Tsutsumi, 2013).

The Weihe Graben is one of the intracontinental graben systems that has developed around the Ordos Block in central China since the Eocene, and it provides a unique natural laboratory for studying the long-term tectonic history of active intracontinental normal-faults in an extensional environment (Fig. 1). In previous studies, the active faults in this region have been traced as a simple linear structure along the topographic boundary between the Weihe Graben and the Qinling and Huashan Mountains (e.g., Li and Ran, 1983; Zhang et al., 1995; Hou et al., 1998; Yuan and Feng, 2010), but the surface traces, structural features, and geometric distribution of the active faults were not mapped in detail and hence remain unclear. Although it has been inferred that the active faults in the Weihe Graben are dominated by normal slip (SSB, 1988; Deng et al., 2003), a large component of sinistral strike-slip movement has also been suggested (e.g., Li and Ran, 1983; Wang, 1987; Zhang et al., 1998; Mercier et al., 2013), and it seems, therefore, that the sense of tectonic movement is also an issue in dispute.

In this study, we focus on the recent activity, geometric distribution pattern, and, structural features of the active normal faults in the Weihe Graben, and discuss their 
implications for the extensional tectonic deformation in the intracontinental rift basin systems around the Ordos Block, central China.

\section{Tectonic setting}

The Weihe Graben is located at the southern margin of the stable Ordos Block, which has a pre-Mesozoic crystalline basement (Ma and $\mathrm{Wu}, 1987$; SSB, 1988). The graben is bordered to the south by the Qinling Mountains, which were formed by the collision of the North China Craton (NCC) and the South China Block (SCB) in the Triassic (Fig. 1; e.g., Meng and Zhang, 2000; Rastchbacher et al., 2003). The Weihe Graben is just one of several intracontinental graben systems that are developed around the Ordos Block (Fig. 1). As a result of extension, the Weihe Graben has received Cenozoic deposits up to $7000 \mathrm{~m}$ in thickness since the Eocene, and the extension has been accompanied by the uplift of mountainous blocks (e.g., the Huashan Mountains and the Weinan Loess Tableland) along its southern border (SSB, 1988; Zhang et al., 1998; Liu et al., 2013). The upthrown Huashan Mountains are mainly composed of pre-Mesozoic metamorphic basement rocks; in contrast, the Weinan Loess Tableland is characterized by Quaternary loess and alluvial deposits (Fig. 1; SSB, 1988). Fission track dating data have shown that the uplift of the Huashan Mountains started at around 68.2 Ma, and that uplift rates became faster from around 17.8 Ma, with an average rate of $\sim 0.19 \mathrm{~mm} / \mathrm{yr}$ (Yin et al., 2001).

More than 10 large historical earthquakes of $M \geq 7$, including four with $M \geq 8$, have occurred in the graben systems around the Ordos Block, three of those occurred 
in the Weihe Graben (Fig. 1; Deng, 2007). The 1556 M 8.5 Huaxian great

earthquake occurred in the Weihe Graben and caused $>830,000$ deaths, and it has been suggested that an active fault zone ruptured for up to $70 \mathrm{~km}$ along the southern margin of the Ordos Block between the cities of Weinan and Huayin (e.g., Kuo, 1957; Wang, 1980; SSB, 1988; Xie, 1992; CENC, 2007; Yuan and Feng, 2010). The high level of historical seismicity indicates that the normal faults in the Weihe graben are currently active as seismogenic faults (e.g., SSB, 1988; Zhang et al., 1998; Deng, 2007).

\section{Identification of active faults}

Since crustal deformation associated with active faults is represented by displaced landforms on the surface of the Earth, a perspective view of topographic features provides an important method of detecting and identifying active faults. In this study, we identified active faults by using perspective view of high-resolution satellite remote-sensing images $(0.5 \mathrm{~m}$ WorldView and $1 \mathrm{~m}$ IKONOS), together with fieldwork that was guided by the images. The remote-sensing images were processed and analyzed in 3D by draping on the $30 \mathrm{~m}$ resolution ASTER Global Digital Elevation Model (GDEM) data (Figs. 2-4). These multi-perspective views made it possible to identify the active faults more easily than by using traditional methods such as aerial photographs. On the basis of geomorphic markers such as terrace risers and alluvial fans, we were able to identify active fault traces that are mostly perpendicular or oblique to valleys and river channels. As shown in Fig. 2, a series of irregular linear traces is developed near the heads of the alluvial fans along the 
piedmont of the Huashan Mountains, and the traces are characterized by a series of parallel or sub-parallel fault scarps that face NNW. The topographic and structural features of the fault scarps indicate that faulting has taken place since the formation of the alluvial fans, and in combination with the results of radiocarbon dating, it can therefore be demonstrated that the observed faults have been active in the Holocene (Fig. 2; Table 1).

\section{Structural features and activity of the recent faults}

The analysis of the remote sensing images, together with field investigations, shows that the active faults are mainly distributed along the northern marginal zones of the Huashan Mountains and the Weinan Loess Tableland. Numerous discontinuous fault traces are present, and they range in length from a few tens of meters to $450 \mathrm{~m}$ (generally $<200 \mathrm{~m})$ (Figs. 2-4). These faults are mainly characterized by numerous stepped normal fault scarps, which are mostly restricted to a narrow zone $10-500 \mathrm{~m}$ wide (generally $<300 \mathrm{~m}$ ), and the spacing of the individual fault scarps is in the range $\sim 20-200 \mathrm{~m}$ (generally $<100 \mathrm{~m}$ ) (Figs. 2-5). Along these scarps, many outcrops of the faults can be observed in the field, and four typical examples (Locs. 1-4), where the loess, alluvial deposits, and basement rocks are displaced, are described below (Figs. $6-11)$.

At Loc. 1, the stepped fault scarps can be seen along the piedmont of the Huashan Mountains near Huayin city, and the height of each individual fault scarp is as much as $19 \mathrm{~m}$ (Fig. 6a-b; see Figs. 1c and 4b for details of the location). Under one scarp, 
the main shear zone of the fault crops out, and fault breccia and cataclasite sourced from the basement rocks, together with disturbed loess and alluvial deposits, are bounded by distinct fault planes that dip NW at angles of $40^{\circ}-54^{\circ}$ (Fig. 6c, d). The fault breccias are mostly dragged into positions parallel or subparallel to the main fault planes, indicating a slip-sense that is dominantly normal (Fig. 6c, d). Some brownish-gray veins composed of fine-grained microbreccia have been injected into both the loess and sandy gravel deposits, indicating a recent faulting event that cuts all the deposits at this site (Fig. 6d, e). Such injection veins within active fault shear zones have commonly been reported elsewhere, and they are generally considered to form rapidly during large paleo-earthquakes, indicating the co-seismic rupture structure of seismogenic fault zone (e.g., Lin et al., 2012, 2013b).

At Loc. 2, the shear zone of the fault is well exposed in four parallel quarry pits (T1-T4) on the piedmont of the Huashan Mountains (Figs. 7-8; see Figs. 2 and 3a for details of the location). The shear zone is exposed along a fault scarp, approximately $10 \mathrm{~m}$ in height that is developed in the alluvial sediments and loess deposits (Fig. 7). Sketches of the shear zone structures in seven exposures are shown in Fig. 7c; the structures are concentrated in a zone less than $5 \mathrm{~m}$ in width, and 3-5 sub-faults are present. The loess deposits and alluvial sand gravels are downthrown to the north along the main fault planes that dip north at angles of $40^{\circ}-71^{\circ}$, indicating a normal slip-sense, consistent with the topographic features of the stepped fault scarps (Fig. 7c). All the deposits within the shear zone have been disturbed, and the gravels were mostly dragged into positions parallel or subparallel to the main fault planes, with 
some injected into fractures or forming wedge-shaped structures (Figs. 7c and 8). The calcareous materials collected in the loessial deposits which are interlayered by the loess and alluvial deposit composed of sandy gravels, yield radiocarbon ages of 5500-19,450 yr BP (Fig. 7c; Table 1), indicating late Pleistocene-Holocene activity of the faults at this site.

At Loc. 3, the shear zone of the fault was observed at the boundary between basin and mountain, $\sim 600 \mathrm{~m}$ east of Loc. 2 . Here, the fault plane dips north at an angle of $56^{\circ}$, and it separates unconsolidated alluvial deposits in the hanging wall from basement rocks in the footwall (Fig. 9; see Figs. 2 and 3a for details of the location). The shear zone is characterized by a narrow fault gouge and breccia zone less than 30 $\mathrm{cm}$ thick where the sheared material has been mainly dragged into positions parallel or subparallel to the fault plane. Fault steps and striations are present, indicating a mainly normal sense of slip (Fig. 9b-e). The alluvial deposits that bound the shear zone were disturbed and mixed with the fault breccias, and a downthrown movement of hanging wall is indicated, which is also consistent with that indicated by the fault striations and fault steps observed on the main fault plane.

At Loc. 4, fault scarps are developed on the terrace risers of the Chishuihe River along the northern marginal zone of the Weinan Loess Tableland. The scarps are clearly seen in the remote-sensing perspective views (Fig. 10a), and they can also be seen in the field (Fig. 10b-d). The fault outcrops are exposed along both banks of the Chishuihe River, where alluvial sand-pebble and cobble deposits are faulted against weakly consolidated silts and sandstones. The main fault plane strikes $\mathrm{N} 40^{\circ} \mathrm{W}$ and 
dips $\mathrm{NE}$ at an angle of $55^{\circ}$. A fault gouge zone less than $5 \mathrm{~cm}$ thick is present, and fault striations indicate a mainly normal sense of slip, consistent with the sense of movement indicated by the fault scarps at this site (Figs. 10e and 11). The pebbly deposits that bound the main fault plane were mostly dragged into positions parallel or subparallel to the fault plane (Fig. 11a, b). The equal-area projection of measured striations and topographic features indicates an almost pure normal fault movement at this site (Fig. 11c). The deposits of Unit 4 are overlaid by Unit 1-3 in which the current plastic materials are involved, indicating a formation age of $<100$ years. The results of ${ }^{14} \mathrm{C}$ age dating show that the alluvial sediments (Unit 5) in the hanging wall were deposited at 18,270 $\pm 60 \mathrm{yr}$ B.P. indicating activity of the fault since the late Pleistocene (Fig. 11b; Table 1).

\section{Discussion}

\subsection{Geometric characteristics of active normal faults}

Normal faults in the upper crust generally have high dip angles of $\sim 60^{\circ}$, and most large-magnitude earthquakes caused by normal faulting are triggered by faults with dips of $>30^{\circ}$ (e.g., Jackson, 1987; Doser and Smith, 1989). However, many normal faults have a listric geometry, and flatten out with depth (e.g., Shelton, 1984; Xiao and Suppe, 1992); in addition, some seismogenic faults are known to be low-angle normal faults (e.g., Abers et al., 1997; Axen, 1999; Abbott et al., 2001), although the mechanism by which they trigger earthquakes is still under debate (e.g., Jackson and White, 1989; Lecomte et al., 2012). As stated above, the dip angles of the main faults 
in the Weihe graben vary from $40^{\circ}$ to $71^{\circ}$, but are mostly $>50^{\circ}$, consistent with the subsurface fault geometry revealed by seismic reflection data (Xie et al., 2011). Previous study also showed that the dip angles of the active faults in the study area range from $45^{\circ}$ to $80^{\circ}$, which were measured in the field (SSB, 1988). It seems clear, therefore, that the active normal faulting in the study area is not on low-angle structures at the near-surface, reflecting the middle-high dip angle of seismogenic fault zone.

In plan view, the surface traces of active faults in the study area are characterized by numerous discontinuous and short lineaments with variable trends, and they are mostly distributed in a zone 10-500 m wide (Figs. 2-4). These geometric features contrast with those reported in previous studies where the surface fault traces were inferred to form a simple straight lineament along the topographic boundary between the mountains and the basin; however, the geometry and distribution pattern of the active faults were not mapped in detail (e.g., Li and Ran, 1983; Zhang et al., 1995; Hou et al., 1998). Previous studies also show that a single fault zone and/or a co-seismic surface rupture zone occurred along a pre-existing active fault is generally characterized by numerous fault stands formed a zone ranging from a few meters to hundreds meters in width at surface (e.g., Steven et al., 1996; Lin et al., 2002, 2009; Kim et a., 2004; Berg and Skar, 2005). The parallel-subparallel active fault traces identified in the remote-sensing images have also been confirmed in the field, as noted above, and they are characterized by stepwise fault scarps with similar orientations, and they form steep slopes in topographic profiles (Figs. 2-5). Such 
geometric features are comparable with those of typical active normal fault zones in extensional tectonic regimes worldwide (e.g., Armijo et al., 1986; Yeats et al., 1997; McCalpin, 2009). Based on geological and geophysical data, the stepwise fault scarps are generally considered to be a response to the refraction of master fault-planes bounding the graben (e.g., Gibbs, 1984; Stewart and Hancock, 1991; McCalpin, 2009). In the study area, seismic reflection data also show that the stepwise faults join together in a master fault below the surface (e.g., Xie et al., 2011). Our findings show that the active normal faults developed in the Weihe Graben have irregular geometries, trends, distributions, and continuity, and at the surface they do not form a regular straight lineament as previously reported.

\subsection{Slip rates}

The slip rate of an active fault is an important and quantitative parameter for assessing the seismic hazard and tectonic activity of the fault, including the recurrence interval of large earthquakes (e.g., Yeats et al., 1997; McCalpin, 2009). Two factors generally affect the precision of slip-rate estimates in extensional regimes: the actual amount by which topographic markers have been offset, and the age of any surface displacement marker. An estimate of the amount of offset mainly depends on the distribution pattern and geometric characteristics of the active fault, as determined by field mapping, especially in regions, such as the present study area, that are characterized by a stepwise distribution of faults. Neighboring normal faults with similar orientations commonly slip at different rates, and they may be active over different time intervals 
(Cowie and Roberts, 2001); in some cases it may be difficult to distinguish a tectonic fault from a gravitational fault such as the slide surface formed during landsliding (e.g., Moro et al., 2012; Carbonel et al., 2013). Therefore, care must be taken when choosing sites for assessing slip rates.

Previous researchers have estimated slip rates for the active normal faults in the Weihe Graben of 1-3 mm/yr (Li and Ran, 1983; SSB, 1988; Deng et al., 2003) to 10.4 $\mathrm{mm} / \mathrm{yr}$ (Li and Ran, 1983). These estimates differ by one order of magnitude, and they remain open to dispute; clearly, the slip rates of the active normal faults in the Weihe Graben are poorly constrained. These slip rates were generally estimated on the presumption that the faults formed simple straight lineaments. There was no detailed mapping of the geometric patterns and fault distribution, and no accurate dating of surface markers; instead, various inferred ages of displaced landforms were used, involving large uncertainties ( $\mathrm{Li}$ and Ran, 1983; SSB, 1988). In other words, the large differences among the previous calculations of slip rates probably resulted from a lack of knowledge of the detailed geometry of the active faults, and a lack of reliable age constraints for the surface markers that are offset and deformed. Variation of slip-rates (extension rate of the Graben) might also be affected by the inherited Mesozoic and Cenozoic structures with complex deformation history (e.g., Mercier et al., 2013), as well as the far field effects of the India-Asian collision (e.g., Zhang et al., 1998; Liu et al., 2004).

As stated above, the late Pleistocene-Holocene terrace risers, alluvial fans, and loess slopes have all been systematically displaced, and we have used them as 
topographic surface markers for estimating slip rates. The loess is wind-borne sediment that contains calcareous materials that can be used for radiocarbon dating (Ding et al., 1994), and this allows the loess sequences to be used for assessing the ages of surface markers such as the loess plateau surface and alluvial fans.

Radiocarbon dating results give ages that are generally younger than $20 \mathrm{ka}$ for the alluvial fans and the loess plateau surfaces on which the stepwise fault scarps are developed (Figs. 7 and 11; Table 1).

On the basis of our observations, the active deformation zones are mainly characterized by a series of stepped fault scarps. Therefore, the total vertical offset can be estimated by summing the vertical offsets of individual fault scarps across the fault zone (Fig. 5). To avoid the effects of variations in the geometric distribution of the fault traces, we selected six typical topographic profiles across the fault zone to measure the total vertical offset amounts; the profiles range from $15 \mathrm{~m}$ to $80 \mathrm{~m}$ in length (generally 30-40 m) (Fig. 5; Table 2). The results of radiocarbon dating show that the loess plateau surfaces and alluvial terrace risers formed at around 5500 to 16,000 yr. B.P. (Tables 1 and 2). Accordingly, the slip rates are calculated to be in the range $2.1-5.7 \mathrm{~mm} / \mathrm{yr}$, with an average value of $\sim 4 \mathrm{~mm} / \mathrm{yr}$ (Table 2 ). Our results contrast with those previously estimated (between $1-3 \mathrm{~mm} / \mathrm{yr}$ and $10.4 \mathrm{~mm} / \mathrm{yr}$ ).

\subsection{Tectonic implications for intracontinental rift basins}

Understanding the geometric and kinematic characteristics of active normal faults in the Weihe Graben would assist in investigating seismotectonic features and the 
tectonic-sedimentary evolution of active extensional basins around the Ordos Block (e.g., Peltzer et al., 1985; Zhang et al., 1985, 1998). The active normal faults identified in this study are mostly developed along the northern margins of the Huashan Mountains and Weinan Loess Tableland, and they are characterized by pure dip-slip movements (Fig. 12a) that indicate a NW-SE extensional stress-direction, consistent with the regional extensional stress-direction inferred from earthquake mechanisms (Ma et al., 1989). Moreover, this result is in general agreement with GPS observations that show crustal movement velocities within the entire North China Craton decelerate gradually from WNW to ESE (e.g., Wang et al., 2001). Furthermore, the complex geometry and distribution pattern of the surface fault trends mapped in the study area show that the map patterns of normal faults are highly irregular, similar to those of co-seismic surface zones caused by large earthquakes in the intracontinental rift environments, such as the 1954 Dixie Valley earthquake $\left(M_{s} 7.2\right)$ and 1915 Pleasant Valley earthquake $\left(M_{s} 7.6\right)$ (Yeats et al., 1997), which provide us the mapped patterns of fault trends for assessing the normal faulting process and slip rate of active normal faults that triggered a giant earthquake $(\mathrm{M} \sim 8.5)$ in the Weihe Graben as documented above.

The Weihe Graben can be classified as a traditional rift basin (e.g., Friedmann and Burbank, 1995), characterized by thick half-graben sediments (>7000 m), a long history ( 50 Ma) (e.g., SSB, 1988; Zhang et al., 1998; Liu et al., 2013), and normal faults with high dip angles $\left(40^{\circ}-71^{\circ}\right.$; this study). The variations in the lithospheric structure (crustal thinning) of the Weihe rift basin relative to its neighboring regions 
are probably the result of extension in the lower crust due to underlying asthenospheric mantle flow (Fig. 12b), as revealed by geophysical observations (e.g., Huang et al., 2008; Bao et al., 2011). On the basis of numerical simulations and shear wave splitting analysis, it has been suggested that the structures in the mantle were affected by the collision of the North and South China blocks in the Mesozoic, with the lateral flow of the mantle caused by driving forces associated with Indo-Asian collision (Liu et al., 2004; Huang et al., 2008).

The active normal faults are currently under an ongoing extensional environment, which is probably related to the pre-existing spreading and rifting of the continental crust in this area (in contrast to the Ordos Block and other neighboring orogenic regions) (Fig. 12b). Because of the absence of magma activity, the strain accumulated within the brittle upper crust is thought to have been released mainly by repeated movements along the active normal faults. These movements have caused major earthquakes such as the $1556 \mathrm{M} \sim 8.5$ Huaxian great earthquake, the relative uplift of adjacent mountainous blocks (e.g., the Huashan Mountains and the Weinan Loess Tableland), and the accumulation of a thick succession of sediments in the rift basin (Fig. 12). However, more work is required if we are to have a better understanding of the nature of the deformation associated with the seismogenic source fault that triggered the 1556 earthquake, and if we wish to improve our assessments of the seismic hazards within the densely populated area of the Weihe Graben.

Similar lithospheric structures have been observed in association with other rift basins around the Ordos Block, such as in the Yinchuan Graben (e.g., Zhang et al., 
1985; Ye et al., 1987; SSB, 1988; Tian et al., 2011). We suggest, therefore, that our findings concerning the tectonic activity and structural features of active normal faults in the Weihe Graben, in combination with geophysical observations of the underlying lithospheric structures, will assist in understanding the seismogenic mechanisms of other large intracontinental earthquakes caused by normal-faulting around the Ordos Block (e.g., Zhang et al., 1985; Huang et al., 2008; Bao et al., 2011), and also provide insights into the Cenozoic extensional deformation in these graben systems (e.g., SSB, 1988; Zhang et al., 1998; He et al., 2004).

\section{Conclusions}

On the basis of the analysis of remote-sensing images, combined with field investigations, we have reached the following conclusions.

(i) Active normal faults are mainly developed within a zone $<500 \mathrm{~m}$ wide along the southern border of the eastern part of the Weihe Graben.

(ii) The observed active faults are characterized by a distinctive series of stepped fault scarps that dip into the graben at angles of $40^{\circ}-71^{\circ}$. The fault traces themselves are discontinuous, with individual lengths ranging from a few tens of meters to $450 \mathrm{~m}$ (generally $<200 \mathrm{~m}$ ).

(iii) Topography, geomorphic features, and striations developed on the main fault planes indicate an almost pure normal sense of slip.

(iv) Late Pleistocene-Holocene terrace risers, loess, and alluvial fan deposits have been offset vertically by up to tens of meters, and the estimated 
average dip-slip rate (throw-rate) is $3.0-4.0 \mathrm{~mm} / \mathrm{yr}$.

(v) The normal faults in the Weihe Graben are currently active under an ongoing extensional regime, which is probably related to the pre-existing spreading and rifting of the continental crust in this area (in contrast to the Ordos Block and other neighboring orogenic regions).

\section{Acknowledgements}

We thank Earth Remote Sensing Data Analysis Center (ERSDAC) for making ASTER GDEM data freely available from their web site. This work was supported by the Science Project (Project no. 23253002 awarded to A. Lin) from the Ministry of Education, Culture, Sports, Science and Technology of Japan and partially by the National S \& T Major Project of China (2011ZX05003-002 and 2011ZX05009-001).

\section{References}

Abbott, R.E., Louie, J.N., Caskey, S.J. and Pullammanappallil, S., 2001. Geophysical confirmation of low-angle normal slip on the historically active Dixie Valley fault, Nevada. Journal of Geophysical Research 106, 4169-4181.

Abers, G.A., Mutter, C.Z. and Fang, J., 1997. Shallow dips of normal faults during rapid extension: Earthquakes in the Woodlark-D'Entrecasteaux rift system, Papua New Guinea. Journal of Geophysical Research 102, 15301-15317.

Armijo, R., Tapponnier, P., Mercier, J.L. and Tong-Lin, H., 1986. Quaternary extension in southern Tibet: field observations and tectonic implications. Journal 
of Geophysical Research 91, 13803-13872.

Axen, G.J., 1999. Low-angle normal fault earthquakes and triggering. Geophysical Research Letters 26, 3693-3696.

Bao, X., Xu, M., Wang, L., Mi, N., Yu, D., and Li, H., 2011. Lithospheric structure of the Ordos Block and its boundary areas inferred from Rayleigh wave dispersion. Tectonophysics 499, 132-141.

Berg, S.S. and Skar, T., 2005. Controls on damage zone asymmetry of a normal fault zone: outcrop analyses of a segment of the Moab fault, SE Utah. Journal of Structural Geology 27, 1803-1822.

CENC (China Earthquake Networks Center), 2007, The 1556 Huaxian great earthquake, Shaanxi, China: the largest total of fatalities ever claimed (in Chinese). Available online at: http://www.csi.ac.cn/manage/html/4028861611c5c2ba0111c5c558b00001/_histor y/hxz/qyzhenhai/zh20060609002.htm (Last accessed 10 October 2013)

Carbonel, D., Gutiérrez, F., Linares, R., Roqué, C., Zarroca, M., McCalpin, J., Guerrero, J., and Rodríguez, V., 2013. Differentiating between gravitational and tectonic faults by means of geomorphological mapping, trenching and geophysical surveys. The case of the Zenzano Fault (Iberian Chain, N Spain). Geomorphology189, 93-108.

Crone, A.J., Machette, M.N., Bonilla, M.G., Lienkaemper, J.J., Pierce, K.L., Scott, W.E., Bucknam, R.C., 1987. Surface faulting accompanying the Borah Peak earthquake and segmentation of the lost river fault, central Idaho. Bulletin of the 
Seismological Society of America 77, 739-770.

Cowie, P.A., and Roberts, G.P., 2001. Constraining slip rates and spacings for active normal faults. Journal of Structural Geology 23, 1901-1915.

Deng, Q., 2007. Active Tectonics Map of China, Seismological Press (in Chinese).

Deng, Q., Zhang, P., Ran, Y., Yang, X., Min, W., and Chu, Q., 2003. Basic

characteristics of active tectonics of China. Science In China Series D 46, $356-372$.

Ding, Z.L., Yu, Z., Rutter, N., Liu, T., 1994. Towards an orbital time scale for Chinese loess deposits. Quaternary Science Reviews, 31, 39-70.

Doser, D.I. and Smith, R.B., 1989. An assessment of source parameters of earthquakes in the cordillera of the western United States. Bulletin of the Seismological Society of America 79, $1383-1409$.

Friedmann, S.J. and Burbank, D.W., 1995. Rift basins and supradetachment basins: intracontinental extensional end-members. Basin Research 7, 109-127.

Gibbs, A.D., 1984. Structural evolution of extensional basin margins. Journal of the Geological Society 141, 609-620

Guo, J., Zheng, J., Guan, B., Fu, B., Shi, P., Du, J., Xie, C., and Liu, L., 2012. Coseismic Surface Rupture Structures Associated with $2010 \mathrm{M}_{\mathrm{s}} 7.1 \mathrm{Yushu}$ Earthquake, China. Seismological Research Letters 83, 109 -118.

Harrison, T.M., Copeland, P., Kidd, W.S.F. and Yin, A., 1992. Raising Tibet. Science $255,1663-1670$

Harvard University (2014)._Global CMT Catalog Search. Available online at: 
http://www.globalcmt.org/CMTsearch.html (last accessed 5 April 2014).

He, J., Cai, D., Li, Y. and Gong, Z., 2004. Active extension of the Shanxi rift, north China: does it result from anticlockwise block rotations? Terra Nova 16, 38-42.

Hou, J., Han, M., Chai, B. and Han, H., 1998. Geomorphological observations of active faults in the epicentral region of the Huaxian large earthquake in 1556 in Shaanxi Province, China. Journal of Structural Geology 20, 549-557.

Huang, Z., Xu, M., Wang, L., Mi, N., Yu, D., and Li, H., 2008. Shear wave splitting in the southern margin of the Ordos Block, north China. Geophysical Research Letters 35, L19301. http://dx.doi.org/10.1029/2008GL035188 .

Jackson, J.A., 1987. Active normal faulting and crustal extension. Geological Society, London, Special Publications 28, 3-17.

Jackson, J.A. and White, N.J., 1989. Normal faulting in the upper continental crust: observations from regions of active extension. Journal of Structural Geology 11, $15-36$.

Jia, D., Li, Y., Lin, A., Wang, M., Chen, W., Wu, X., Ren, Z., Zhao, Y., and Luo, L., 2010. Structural model of $2008 \mathrm{M}_{\mathrm{w}} 7.9$ Wenchuan earthquake in the rejuvenated Longmen Shan thrust belt, China. Tectonophysics 491, 174-184.

Kim, Y.-S., Peacock, D.C.P., Sanderson, D.J., 2004. Fault damage zones. Journal of Structural Geology 26, 503-517.

Kuo, T., 1957. On the Shensi earthquake of January 23, 1556. Acta Geophysica Sinica, 6, 59-68 (in Chinese with English abstract).

Lecomte, E., Le Pourhiet, L. and Lacombe, O., 2012. Mechanical basis for slip along 
low-angle normal faults. Geophysical Research Letters 39, L03307.

http://dx.doi.org/10.1029/2011GL050756.

Li and Ran, 1983. Active faults along the north margins of Huashan and Weinan

Loess Tableland. North China Earthquake Science 1, 10-18 (in Chinese with

English abstract).

Li, Y., Jia, D., Shaw, J.H., Hubbard, J., Lin, A., Wang, M., Luo, L., Li, H., and Wu, L., 2010. Structural interpretation of the coseismic faults of the Wenchuan earthquake: Three-dimensional modeling of the Longmen Shan fold-and-thrust belt. Journal of Geophysical Research 115, B04317.

http://dx.doi.org/10.1029/2009JB006824

Lin, A., Fu, B., Guo, J., Zeng, Q., Dang, G., He, W., and Zhao, Y., 2002. Co-seismic strike-slip and rupture length produced by the $2001 \mathrm{M}_{\mathrm{s}} 8.1$ central Kunlun earthquake. Science 296, 2015-2017.

Lin, A., Rao, G., Jia, D., Wu, X., Yan, B., and Ren, Z., 2011. Co-seismic strike-slip surface rupture and displacement produced by the $2010 \mathrm{M}_{\mathrm{W}} 6.9$ Yushu earthquake, China, and implications for Tibetan tectonics. Journal of Geodynamics 52, 249-259.

Lin, A., Ren, Z., Jia, D. and Wu, X., 2009. Co-seismic thrusting rupture and slip distribution produced by the $2008 \mathrm{M}_{\mathrm{w}}$ 7.9 Wenchuan earthquake, China. Tectonophysics 471, 203-215.

Lin, A., Shin, J., and Kano, K., 2012. Fluidized Cataclastic Veins along the Itoigawa-Shizuoka Tectonic Line Active Fault System, Central Japan, and Its 
Seismotectonic Implications. The Journal of Geology 120, 453-465.

Lin, A., Toda, S., Rao, G., Tsuchihashi, S. and Yan, B., 2013a. Structural Analysis of Coseismic Normal Fault Zones of the $2011 \mathrm{M}_{\mathrm{w}}$ 6.6 Fukushima Earthquake, Northeast Japan. Bulletin of the Seismological Society of America 103, 1603-1613.

Lin, A., Yamashita, K., and Tanaka, M., 2013b. Repeated seismic slips recorded in ultracataclastic veins along active faults of the Arima-Takatsuki Tectonic Line, southwest Japan. Journal of Structural Geology 48, 3-13.

Liu, J., Zhang, P., Lease, R., Zheng, D., Wan, J., Wang, W., and Zhang, H., 2013. Eocene onset and late Miocene acceleration of Cenozoic intracontinental extension in the North Qinling range-Weihe graben: Insights from apatite fission track thermochronology. Tectonophysics 584, 281-296.

Liu, M., Cui, X. and Liu, F., 2004. Cenozoic rifting and volcanism in eastern China: a mantle dynamic link to the Indo-Asian collision? Tectonophysics 393, 29-42.

Ma, X. and Wu, D., 1987. Cenozoic extensional tectonics in China. Tectonophysics $133,243-255$.

Ma, X., 1989. Lithospheric Dynamics Atlas of China (in Chinese). China Cartographic Publishing House, Beijing, 548 pp.

McCalpin, J.P., 2009. Paleoseismology, Second Edition. International Geophysics Series, vol. 95, Academic Press 613 pp.

Meng, Q. and Zhang, G., 2000. Geologic framework and tectonic evolution of the Qinling orogen, central China. Tectonophysics 323, 183-196. 
Mercier, J.L., Vergely, P., Zhang, Y.Q., Hou, M.J., Bellier, O., and Wang, Y.M., 2013. Structural records of the Late Cretaceous-Cenozoic extension in Eastern China and the kinematics of the Southern Tan-Lu and Qinling Fault Zone (Anhui and Shaanxi provinces, PR China): Tectonophysics 582, 50-75.

Molnar, P. and Deng, Q., 1984. Faulting associated with large earthquakes and the average rate of deformation in central and eastern Asia. Journal of Geophysical Research 89, 6203-6227.

Molnar, P. and Lyon-Caent, H., 1989. Fault plane solutions of earthquakes and active tectonics of the Tibetan Plateau and its margins. Geophysical Journal International 99, 123-154.

Moro, M., Saroli, M., Gori, S., Falcucci, E., Galadini, F., and Messina, P., 2012. The interaction between active normal faulting and large scale gravitational mass movements revealed by paleoseismological techniques: A case study from central Italy. Geomorphology 151-152, 164-174.

Myers, W.B., and Hamilton, W., 1964. Deformation accompanying the Hebgen Lake earthquake of August 17, 1959. U.S. Geological Survey Professional Paper 435, $55-98$.

Peltzer, G., Tapponnier, P., Zhitao, Z. and Qin, X.Z., 1985. Neogene and Quaternary faulting in and along the Qinling Shan. Nature 317, 500-505.

Rao, G., Lin, A., Yan, B., Jia, D., Wu, X., and Ren, Z., 2011. Co-seismic Riedel shear structures produced by the $2010 \mathrm{M}_{\mathrm{w}} 6.9$ Yushu earthquake, central Tibetan Plateau, China. Tectonophysics 507, 86-94. 
Ratschbacher, L., Hacker, B., Calvert, A., Webb, L., Grimmer, J., McWilliams, M., Ireland, T., Dong, S., and Hu, J., 2003. Tectonics of the Qinling (Central China): tectonostratigraphy, geochronology, and deformation history. Tectonophysics 366 , $1-53$.

Shelton, J.W., 1984. Listric normal faults; an illustrated summary. AAPG Bulletin 68, 801-815.

State Seismological Bureau (SSB), 1988. Active fault system around Ordos Massif (in Chinese). Seismological Press, Beijing, 352 pp.

Steven, D.K., Beach, A., Brockbank, P.J., Brown, J.L., McCallum, J.E., Welbon, A.I., 1996. Spatial and mechanical controls on normal fault populations. Journal of Structural Geology 18, 359-372.

Stewart, I.S. and Hancock, P.L., 1991. Scales of structural heterogeneity within neotectonic normal fault zones in the Aegean region. Journal of Structural Geology 13, 191-204.

Stuiver, M., Reimer, P.J., Reimer, R., 2005. CALIB radiocarbon calibration version 7.0.http://radiocarbon.pa.qub.ac.uk/calib/ (Last accessed, 10 October 2013).

Sun, J., Johnson, K.M., Cao, Z., Shen, Z., Bürgmann, R., and Xu, X., 2011.

Mechanical constraints on inversion of coseismic geodetic data for fault slip and geometry: Example from InSAR observation of the 6 October $2008 \mathrm{M}_{\mathrm{w}} 6.3$ Dangxiong-Yangyi (Tibet) earthquake. Journal of Geophysical Research, 116(B1), B01406. http://dx.doi.org/10.1029/2010JB007849 .

Tapponnier, P. and Molnar, P., 1977. Active faulting and tectonics in China. Journal of 
Geophysical Research 82, 2905-2930.

Tian, X., Teng, J., Zhang, H., Zhang, Z., Zhang, Y., Yang, H., and Zhang, K., 2011.

Structure of crust and upper mantle beneath the Ordos Block and the Yinshan

Mountains revealed by receiver function analysis. Physics of the Earth and

Planetary Interiors 184, 186-193.

Toda, S. and Tsutsumi, H., 2013. Simultaneous Reactivation of Two, Subparallel, Inland Normal Faults during the $\mathrm{M}_{\mathrm{w}} 6.611$ April 2011 Iwaki Earthquake

Triggered by the $\mathrm{M}_{\mathrm{w}} 9.0$ Tohoku-Oki, Japan, Earthquake. Bulletin of the

Seismological Society of America 103, 1584 -1602.

Wallace, R.E., 1984. Fault scarps formed during the earthquake of October 2, 1915, in

Pleasant Valley, Nevada, and some tectonic implications. U.S. Geological Survey Professional Paper 1274-A, 1-33.

Wang, J., 1980. Ground ruptures during the large earthquake of 1556, Huaxian County, Shanxi. Acta Seismologica Sinica 2, 430-437 (in Chinese with English abstract).

Wang, J., 1987. The Fenwei rift and its recent periodic activity. Tectonophysics 133, 257-275.

Wang, Q., Zhang, P., Freymueller, J.T., Bilham, R., Larson, K.M., Lai, X., You, X., Niu, Z., Wu, J., Li, Y., Liu, J., Yang, Z., and Chen, Q., 2001. Present-Day Crustal Deformation in China Constrained by Global Positioning System Measurements. Science 294, 574-577.

West, M.W., 1993. Extensional reactivation of thrust faults accompanied by coseismic surface rupture, southwestern Wyoming and north-central Utah. Geological 
Society of America Bulletin 105, 1137-1150.

Xiao, H. and Suppe, J., 1992. Origin of rollover. AAPG Bulletin 76, 509-529.

Xie, Z., 2011. Structural Model of Earthquake Preparation in Weihe Extensional Basin. Journal of Catastrophology 26, 18-21 (in Chinese with English abstract).

Xie, Y., 1992. On magnitude of 1556 Guanzhong great earthquake. Journal of Catastrophology 7, 10-13 (in Chinese with English abstract)..

Ye, H., Zhang, B. and Mao, F., 1987. The Cenozoic tectonic evolution of the Great North China: two types of rifting and crustal necking in the Great North China and their tectonic implications. Tectonophysics 133, 217-227.

Yeats, R., Seih, K., Allen, C., 1997. The Geology of earthquakes. Oxford University Press, Oxford, 568 pp.

Yuan, T. and Feng X., 2010, The 1556 Huaxian great earthquake (in Chinese), Seismological Press, Beijing, 386 pp.

Yin, A. and Harrison, T.M., 2000. Geologic Evolution of the Himalayan-Tibetan Orogen. Annual Review of Earth and Planetary Sciences 28, 211-280.

Zhang, A., Yang, Z., Zhong, J. and Mi, F., 1995. Characteristics of late quaternary activity along the Southern Border Fault Zone of Weihe Graben Basin. Quaternary International 25, 25-31.

Zhang, B., Jia, S., Wang, T. and Zheng, B., 1985. Intraplate seismotectonic features of North China. Tectonophysics 117, 177-191.

Zhang, Y., Mercier, J.L. and Vergély, P., 1998. Extension in the graben systems around the Ordos (China), and its contribution to the extrusion tectonics of south China 
with respect to Gobi-Mongolia. Tectonophysics 285, 41-75.

2

3 


\section{Figure captions}

Figure 1. (a) Location map of the Weihe Graben, showing the distribution of the major active faults and large historical earthquakes of the graben systems around the Ordos Block [modified from Deng (2007), focal mechanism data from Harvard University (2014)]. The inset map (b) shows the tectonic background. ATF, Altyn Tagh Fault; HYF, Haiyuan Fault; KLF, Kunlun Fault; XSHF, Xianshuihe Fault; SCB, South China Block; QLF, Qinling Fault; LMS, Longmenshan. (c) The color-shaded relief map shows the location and topographic characters of the study area. The red star indicates the epicenter of the $1556 \mathrm{M} \sim 8.5$ Huaxian earthquake (SSB, 1988; CENC, 2007). HPF, Huashan Piedmont Fault; NMF-WLT, North Margin Fault of the Weinan Loess Tableland; LPF, Lishan Piedmont Fault; QPF, Qinling Piedmont Fault; KZ-GSF, Kouzhen-Guanshan Fault.

Figure 2. Perspective view, looking towards the SE, of a $1 \mathrm{~m}$ WorldView image, reveals the active faults developed along the piedmont of the Huashan Mountains. The active fault zones are characterized by stepped normal fault scarps that are restricted to a narrow zone less than $500 \mathrm{~m}$ wide, whereas the lengths of individual fault traces are generally less than $200 \mathrm{~m}$. The faults displace the alluvial fans, the ages of which are constrained to the Holocene by radiocarbon dating (Table 1), indicating the recent activity of the faults. The topographic profiles measured in the field are shown in Fig. 5.

Figure 3. (a) Map showing the distribution of active normal faults in the region 
between Weinan and Huayin cities, the epicentral area of the 1556 M 8.5

Huaxian earthquake. The base map is a south perspective view of the color-shaded relief map based on 30-m resolution ASTER GDEM data. (b-c)

Distribution of active fault traces mapped along the northern margin of the Weinan Loess Tableland.

Figure 4. Map showing the distribution of active fault traces along the piedmont of the Huashan Mountains, identified from the $0.5 \mathrm{~m}$ WorldView (a) and Google Earth images $(b-c)$.

Figure 5. (a-f) Topographic profiles across the active normal fault zones, measured in the field using a laser rangefinder. By summing the individual fault offsets, the cumulative vertical offset amounts for the whole zone of active faulting are estimated, ranging from 15 to $80 \mathrm{~m}$ (generally $30-40 \mathrm{~m}$ ).

Figure 6. (a) Stepped fault scarps developed along the Huashan piedmont (Loc. 1). The person (circled) gives the scale. (b) The height of an individual scarp is as much as $\sim 19 \mathrm{~m}$. (c-d) The main shear zone of the fault is composed mainly of a fault breccia cataclasite, derived from the basement rocks, and disturbed loess and alluvial deposits. The shear zone material is bounded by distinct fault planes that dip NW at angles of $40^{\circ}-54^{\circ}$. (e) Some brownish gray veins composed of a fine-grained microbreccia were injected into both the loess and the sandy gravel deposits.

Figure 7. (a) Close-up view of the 0.5-m resolution WorldView image of Loc. 2. (b) The shear zone of the fault is well exposed in four parallel quarry pits (T1-T4) 
that cut across the 10-m-high fault scarp along the piedmont of the Huashan Mountains. (c) Sketches of seven exposure walls clearly reveal fault planes that dip $\mathrm{N}$ at angles of $40^{\circ}-71^{\circ}$, as well as other fault-related structures such as colluvial wedges and in-filled fissures, which are probably associated with paleoearthquakes. The ${ }^{14} \mathrm{C}$ ages suggest the deformed landforms formed during the late Pleistocene-Holocene (see Table 1 for details).

Figure 8. (a-e) Field photographs show representative outcrops of the fault exposed on the trench walls at Loc. 2, where clear fault planes with high dip angles can be observed. The sand gravels and loess deposits were disturbed, and most were dragged into positions parallel or subparallel to the fault planes (d-e), and some were injected to form the wedge structures and fracture fillings (c). (a): T1-E; (b): T2-W; (c): T3-W; (d-e): T3-E.

Figure 9. (a) The shear zone of the fault observed at Loc. 3 (which is on the topographic boundary between basin and mountain, approximately $600 \mathrm{~m}$ east of Loc. 2). The fault plane dips at a high angle of $56^{\circ}$, and it separates unconsolidated alluvial deposits in the hanging wall from basement rocks in the footwall. (b) The shear zone of the fault is characterized by a narrow fault gouge and breccia zone less than $30 \mathrm{~cm}$ in thickness, in which most of the fault breccias were dragged into positions parallel or subparallel to the fault plane, suggesting a dominantly normal sense of slip, consistent with the observed fault steps and striations (c-e).

Figure 10. (a) 1-m resolution IKONOS image shows the fault scarps developed on 
the terrace risers of the Chishuihe River along the northern margin of the Weinan Loess Tableland. (b) The fault crops out on both banks of the Chishuihe River, and the alluvial deposits of sand-pebble and cobble are faulted against silts and sandstones. Fault gouges and striations were observed on the fault plane. More details of the outcrop are shown in Fig. 11.

Figure 11. (a) Field photograph and corresponding sketch (b) of the fault outcrop at Loc. 4. The pebbly deposits that bound the main fault plane were mostly dragged into positions parallel or subparallel to the fault plane. (c) The equal-area projection of measured striation data and topographic features indicate an almost pure normal slip-sense at this site. The ${ }^{14} \mathrm{C}$ age dating shows that the alluvial sediments in the hanging wall were deposited at $18,270 \pm 60$ yr B.P. (Table 1), indicating recent activity on the fault since the late Pleistocene.

Figure 12. Mode of tectonic deformation in the Weihe Graben. (a) The landscape of the Weihe Graben is controlled by intracontinental normal faulting, resulting in large amounts of subsidence and the accumulation of a thick pile of sediments in the rift basin. Subsurface structures are modified from Wang (1987) and SSB (1988). (b) Active normal faults in the study area formed in a regime of ongoing extension that is probably related to the pre-existing spreading and rifting of the continental crust in this area (in contrast to the Ordos Block and other neighboring orogenic regions). The lithospheric structures are schematic and based on the geophysical data of Bao et al. 
(2011). The vertical depths are not precisely scaled.

2

3

4

5

6 
Table 1 Results of the ${ }^{14} \mathrm{C}$ age dating

\begin{tabular}{|c|c|c|c|c|}
\hline Sample code & Laboratory ID* & Material & ${ }^{14}$ C age $(y r \text { B.P. })^{\dagger}$ & Calendar year $(2 \sigma)^{\S}$ \\
\hline $\mathrm{C} 38$ & Beta-290421* & Shell & $19,450 \pm 80$ & BC 21,734-BC 21,153 \\
\hline C39 & Beta-290422* & Shell & $5,500 \pm 40$ & BC 4,449-BC 4,319 \\
\hline $\mathrm{C} 40$ & Beta-290423* & Shell & $6,330 \pm 40$ & BC 5,379-BC 5,217 \\
\hline $\mathrm{C} 48$ & Beta-290425* & Shell & $6,880 \pm 40$ & BC 5,846-BC 5,671 \\
\hline Shell01 & IAAA-100055** & Shell & $14,050 \pm 50$ & BC $15,386-\mathrm{BC} 14,895$ \\
\hline Shell11 & IAAA-100065** & Shell & $16,270 \pm 50$ & BC 17,912-BC 17,529 \\
\hline C12 & \multicolumn{3}{|c|}{ IAAA-120529** Calcareous soil $18,270 \pm 50$} & BC 20,386-BC 19,966 \\
\hline
\end{tabular}

${ }^{*}$ Samples were analyzed at the BETA Analysis Inc., USA.

${ }^{* *}$ Samples were analyzed at the Institute of Accelerator Analysis Ltd., Japan.

${ }^{\dagger}$ Using Accelerator Mass Spectrometry (AMS) method, referenced to the year A.D. 1950.

${ }^{\S}$ Dendrochronologically calibrated calendar age by Calibration Version 7.0 (Stuiver et al., 2005). 
Table 2 Estimated fault dip-slip rates in Weihe Graben

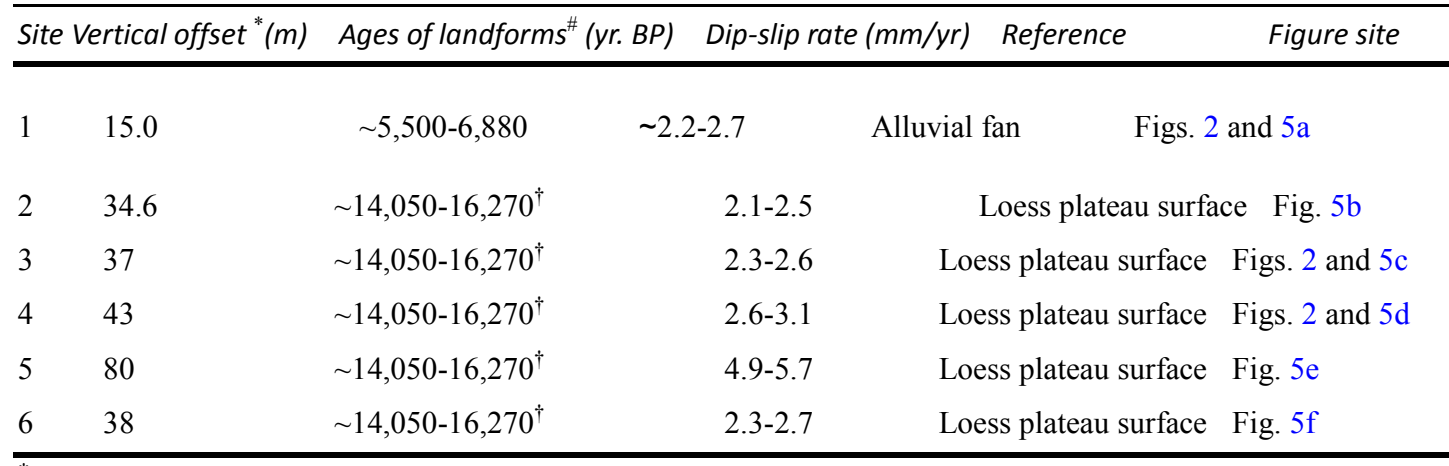

*Cumulative vertical offset value for the whole fault zone.

${ }^{\#}$ The ${ }^{14} \mathrm{C}$ ages referenced to the year A.D. 1950 (see Table 1 for the details).

${ }^{\dagger}$ The ages of regional loess plateau surfaces. 


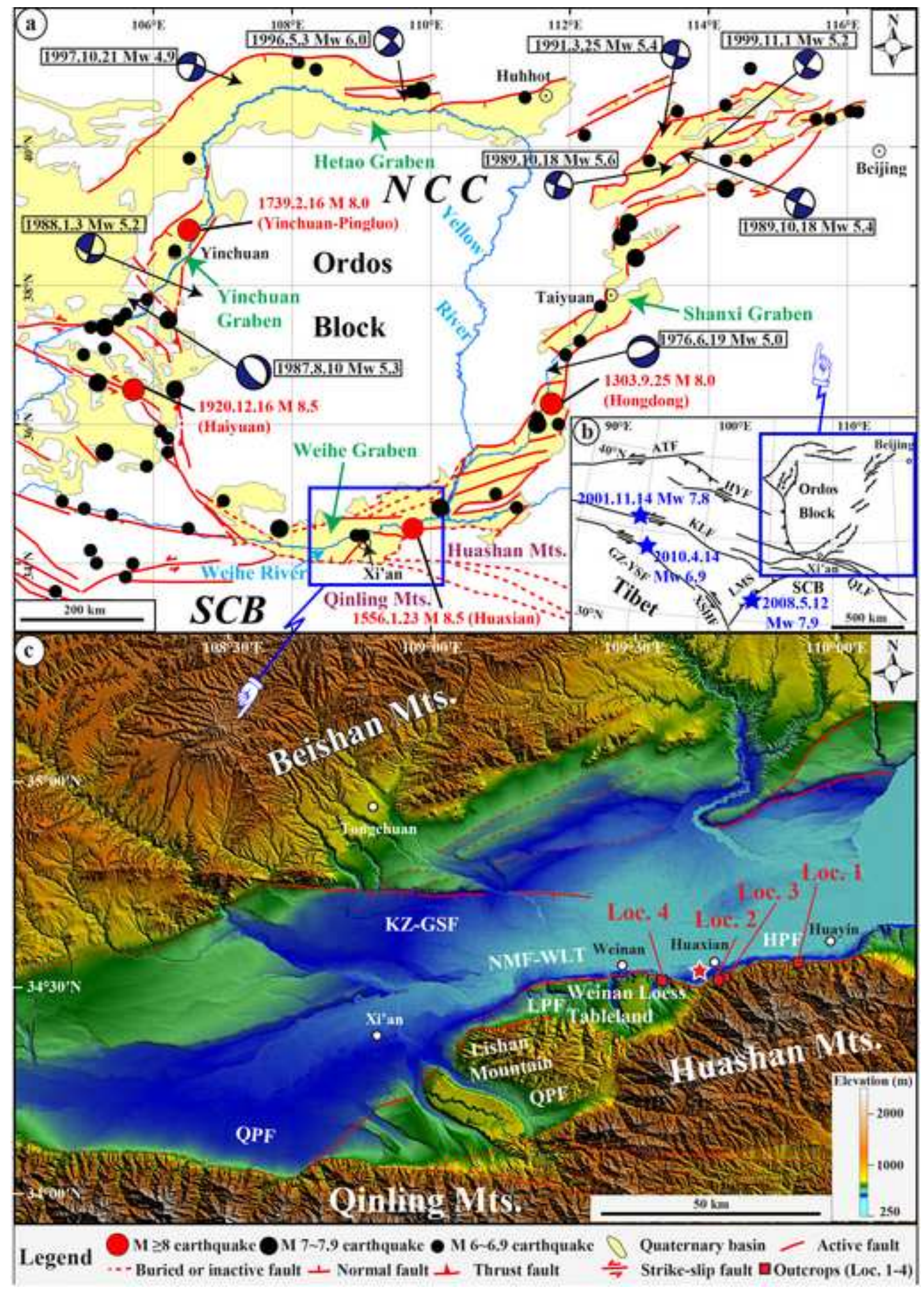


Figure-2
Click here to download high resolution image

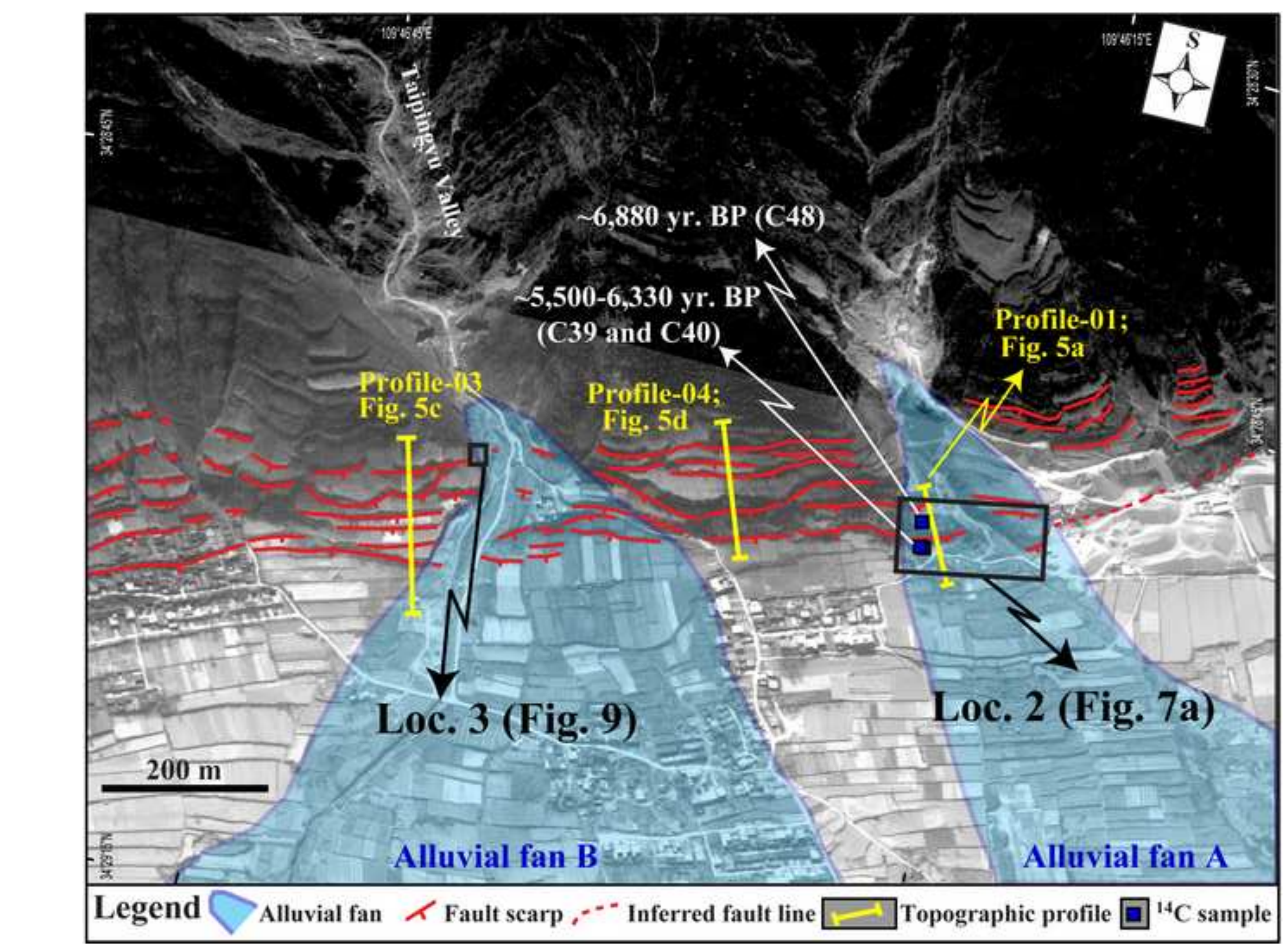

\footnotetext{
to download high resolution image
}

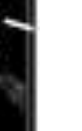

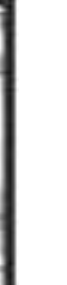

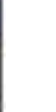
. 


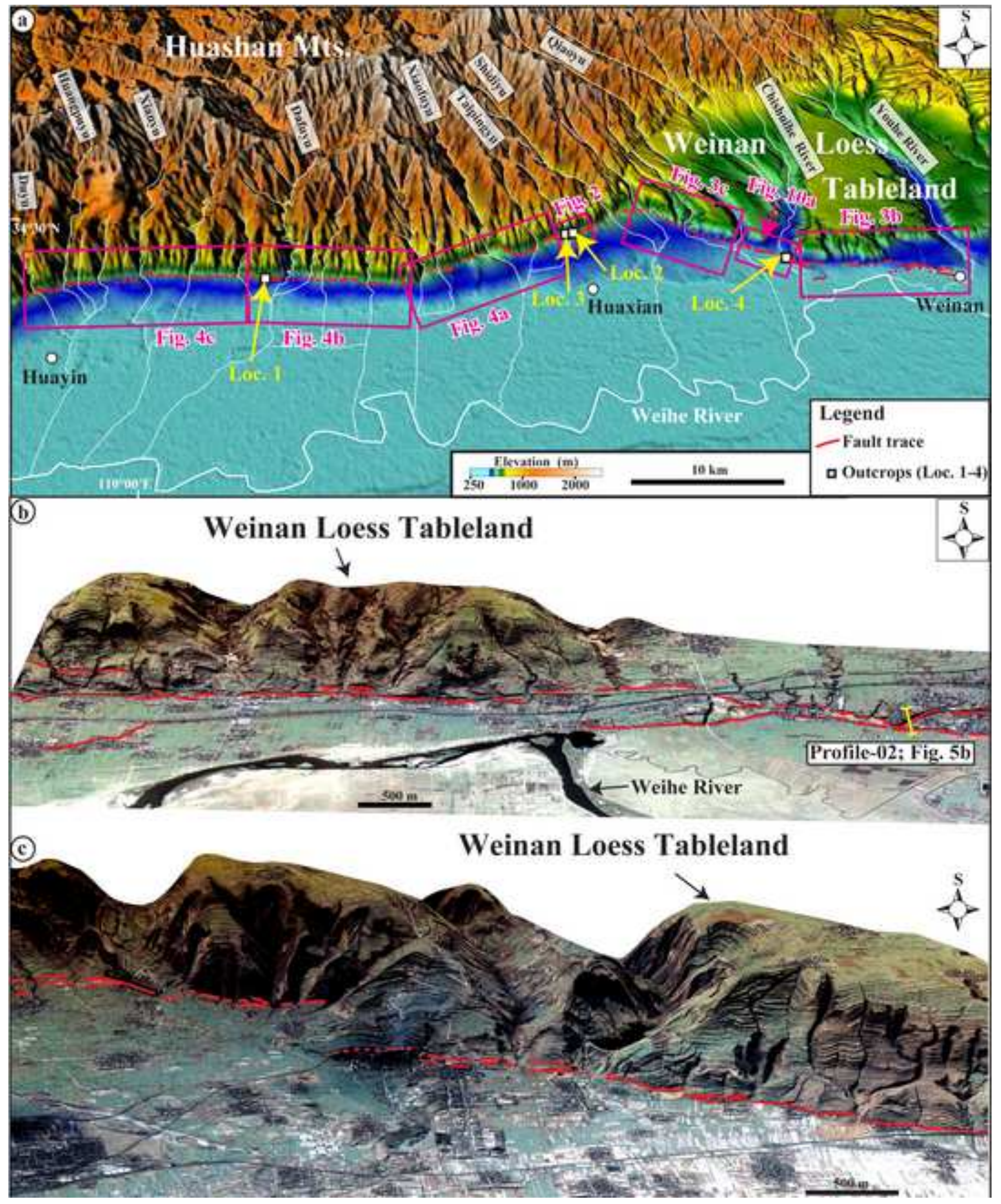


(a)
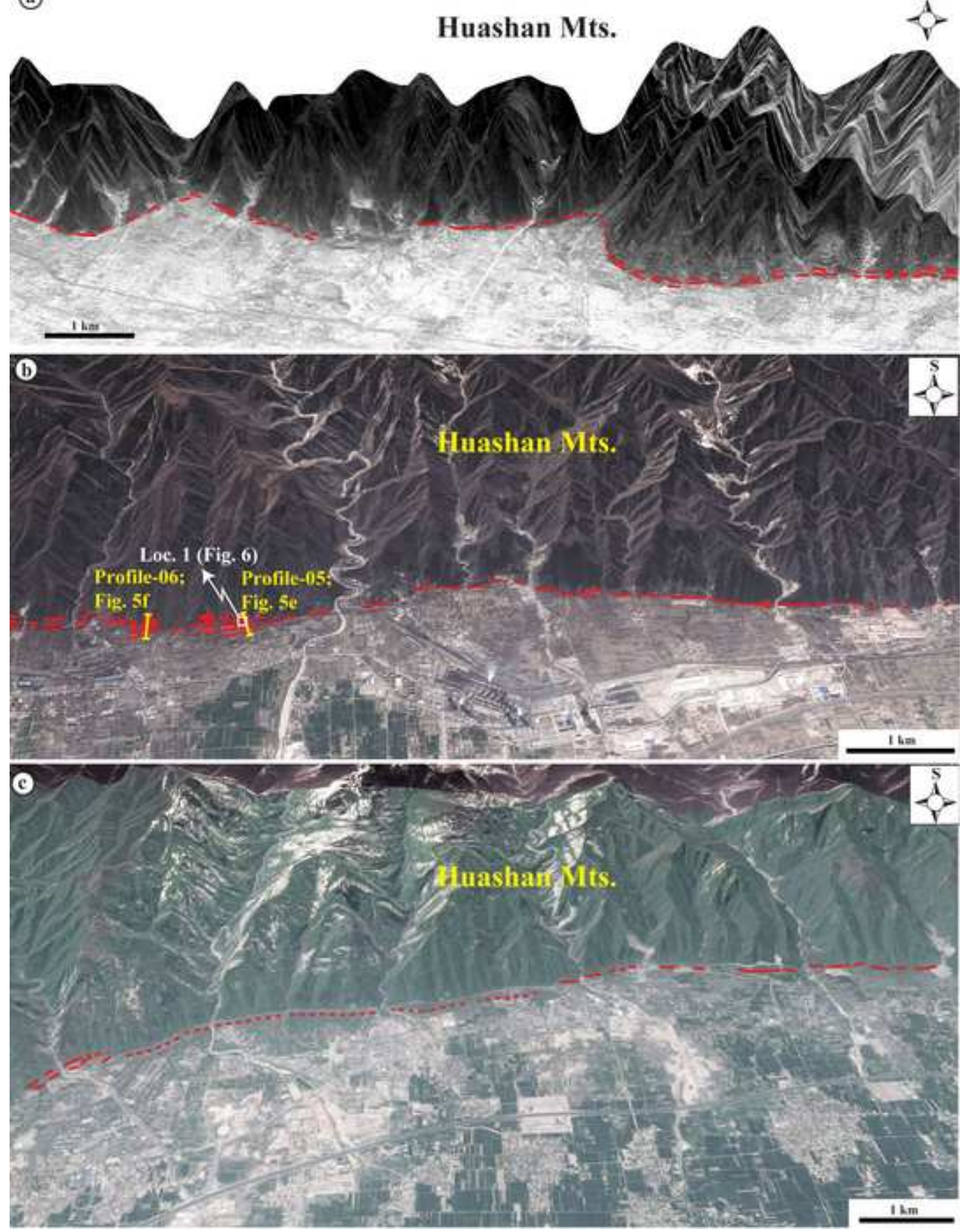
Click here to download high resolution image

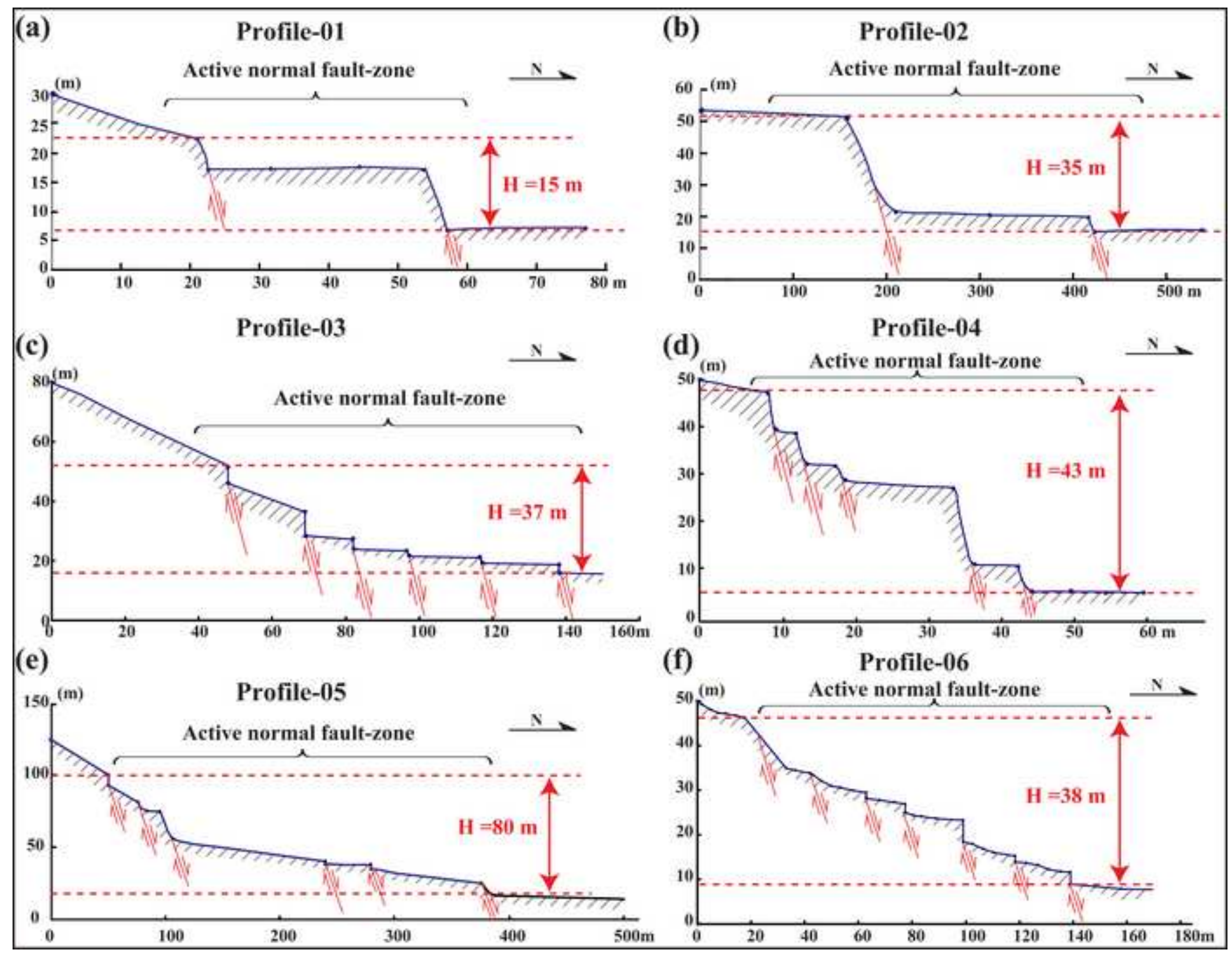



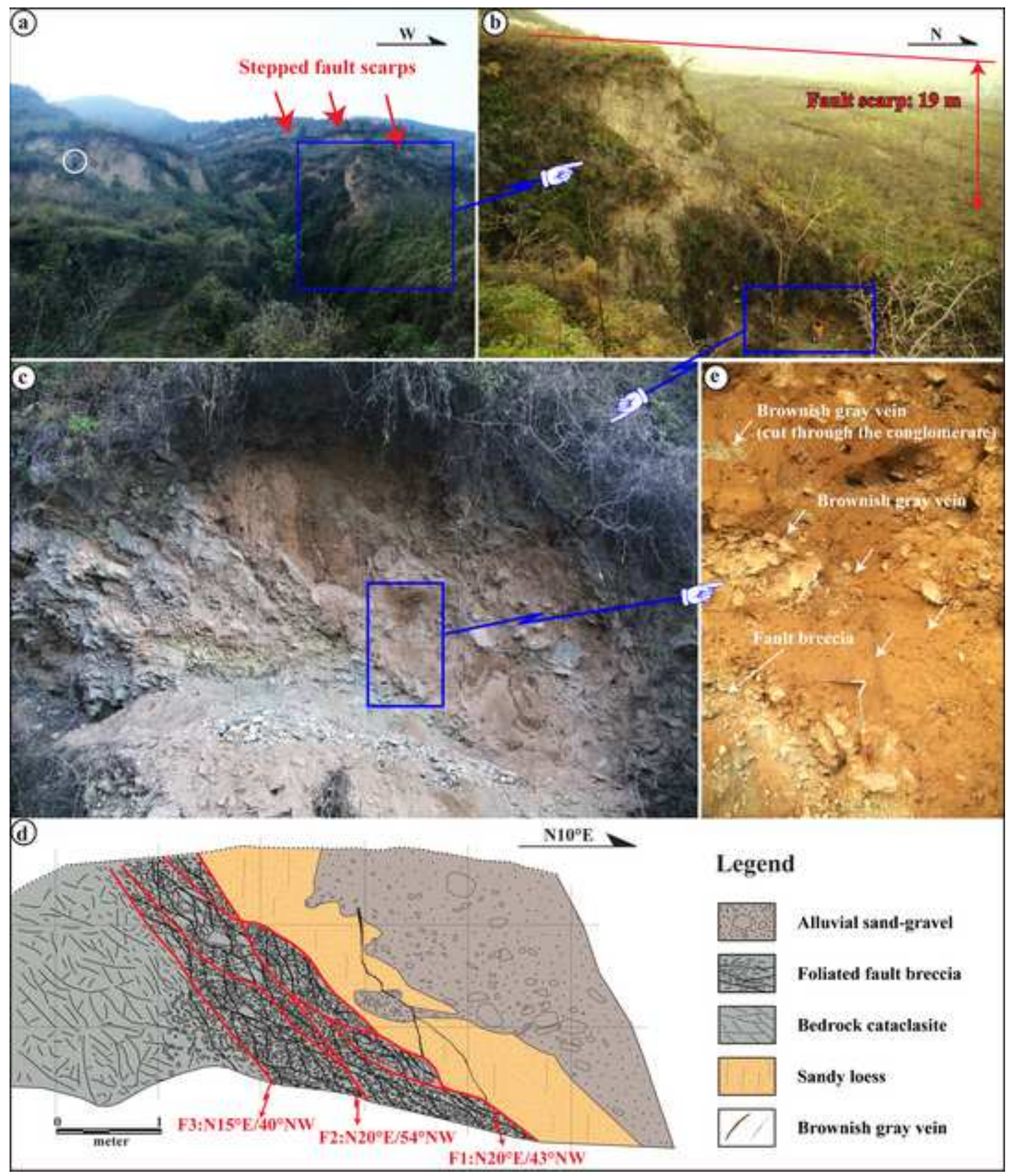

Sandy loess

Brownish gray vein

Legend

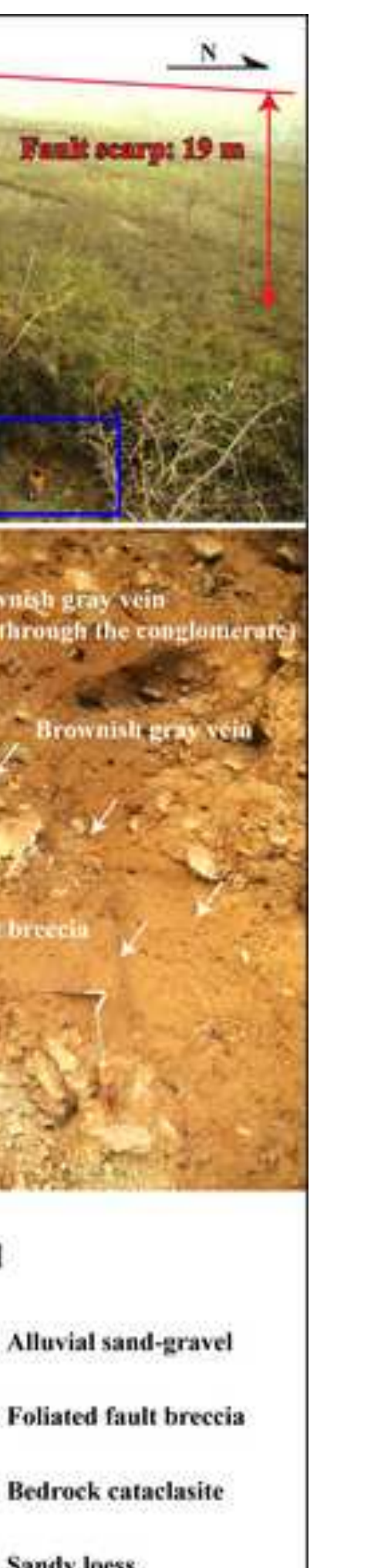

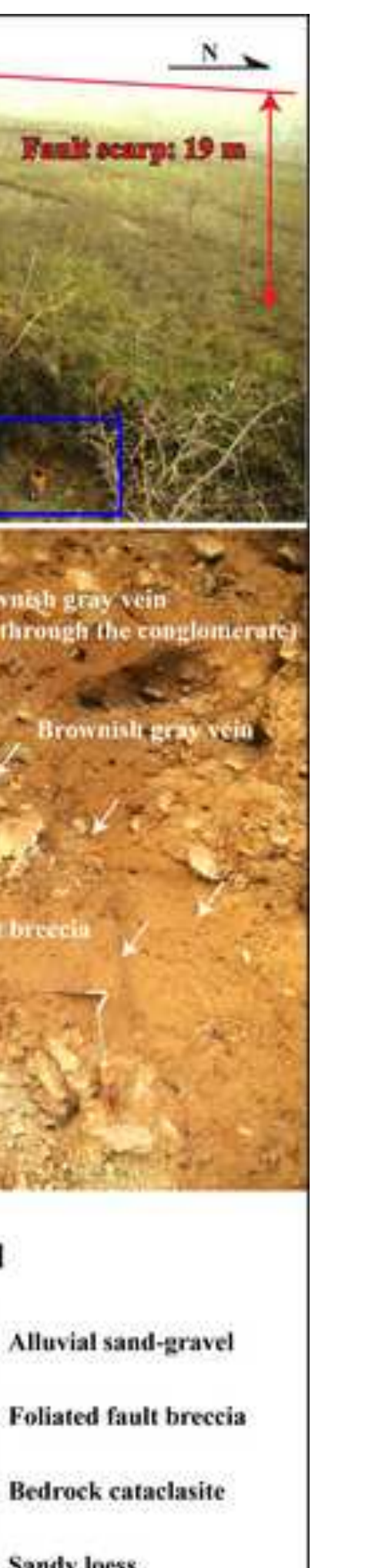

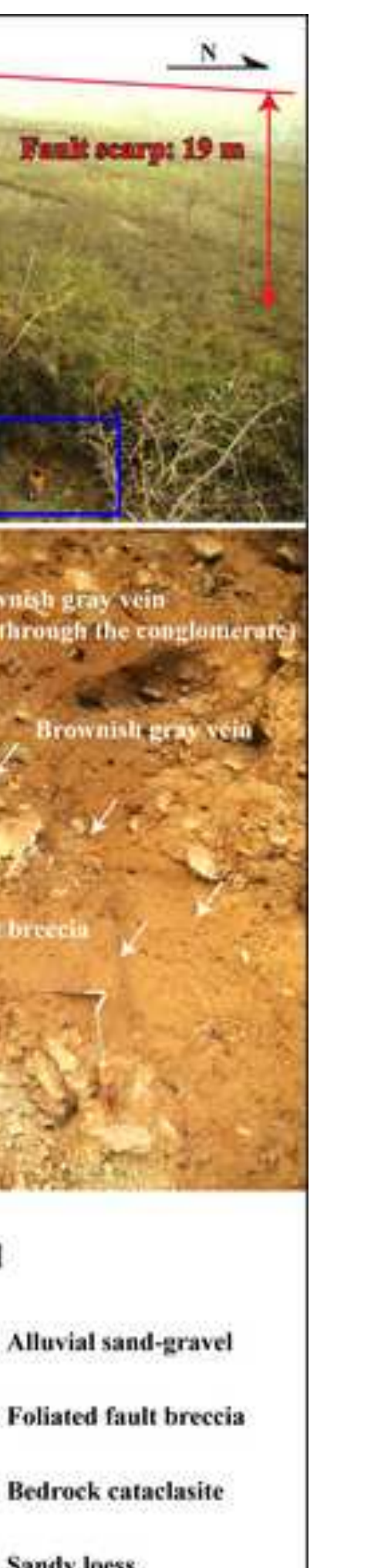

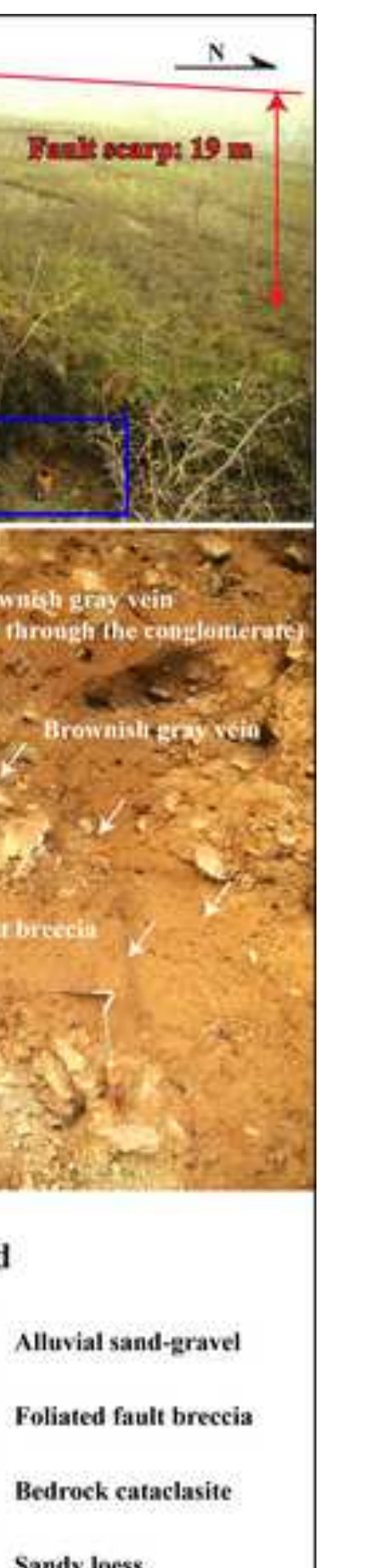

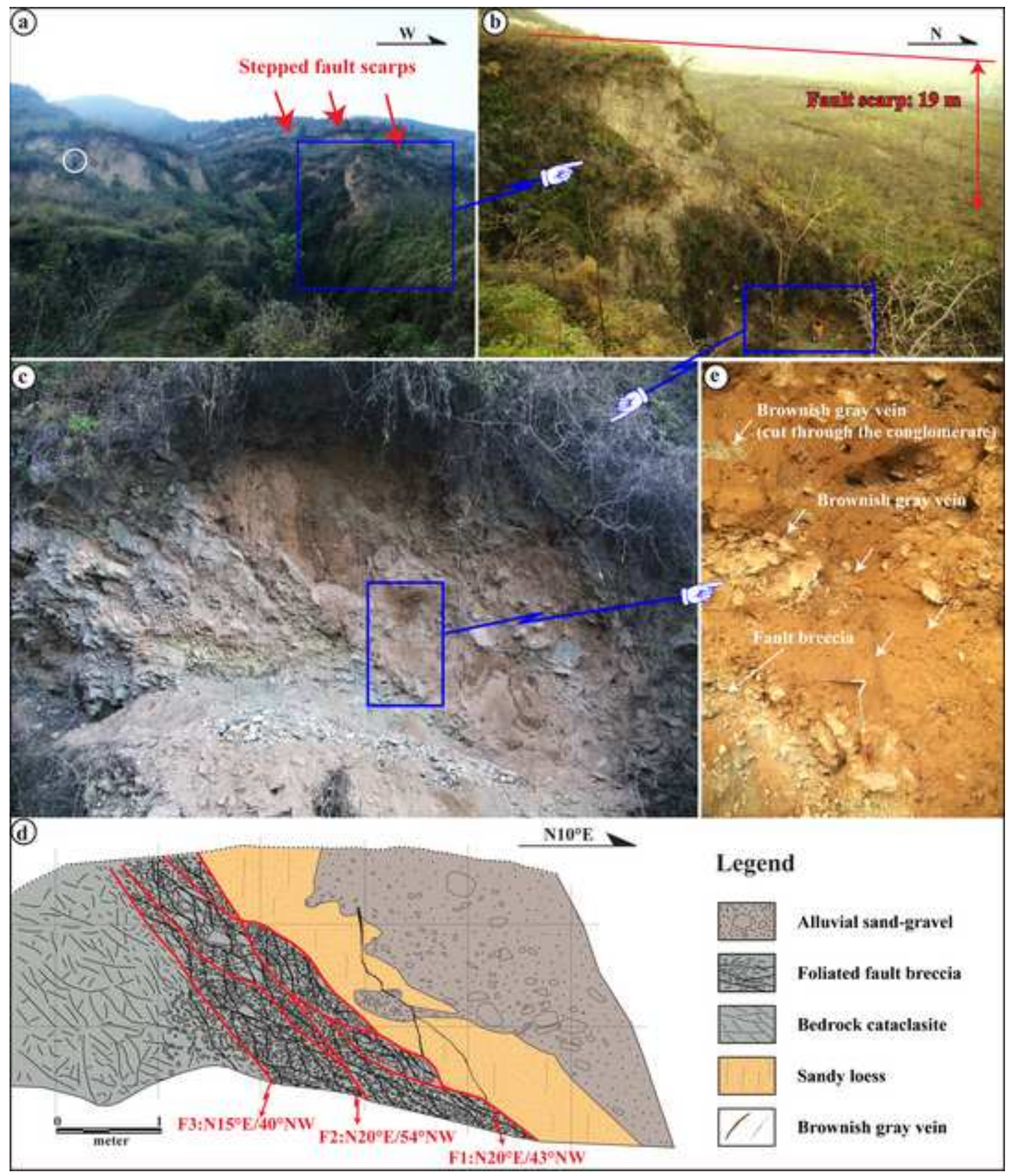




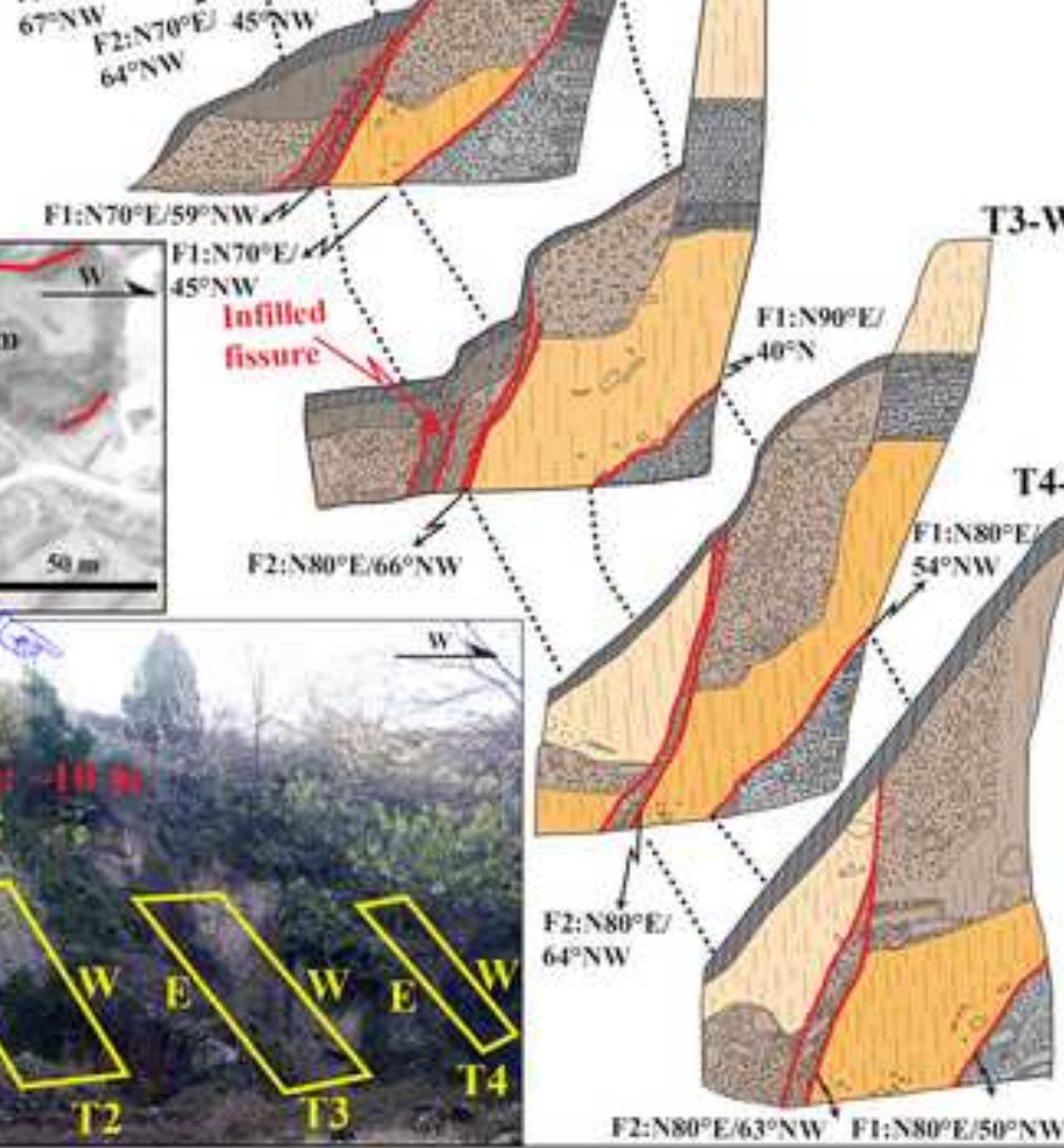




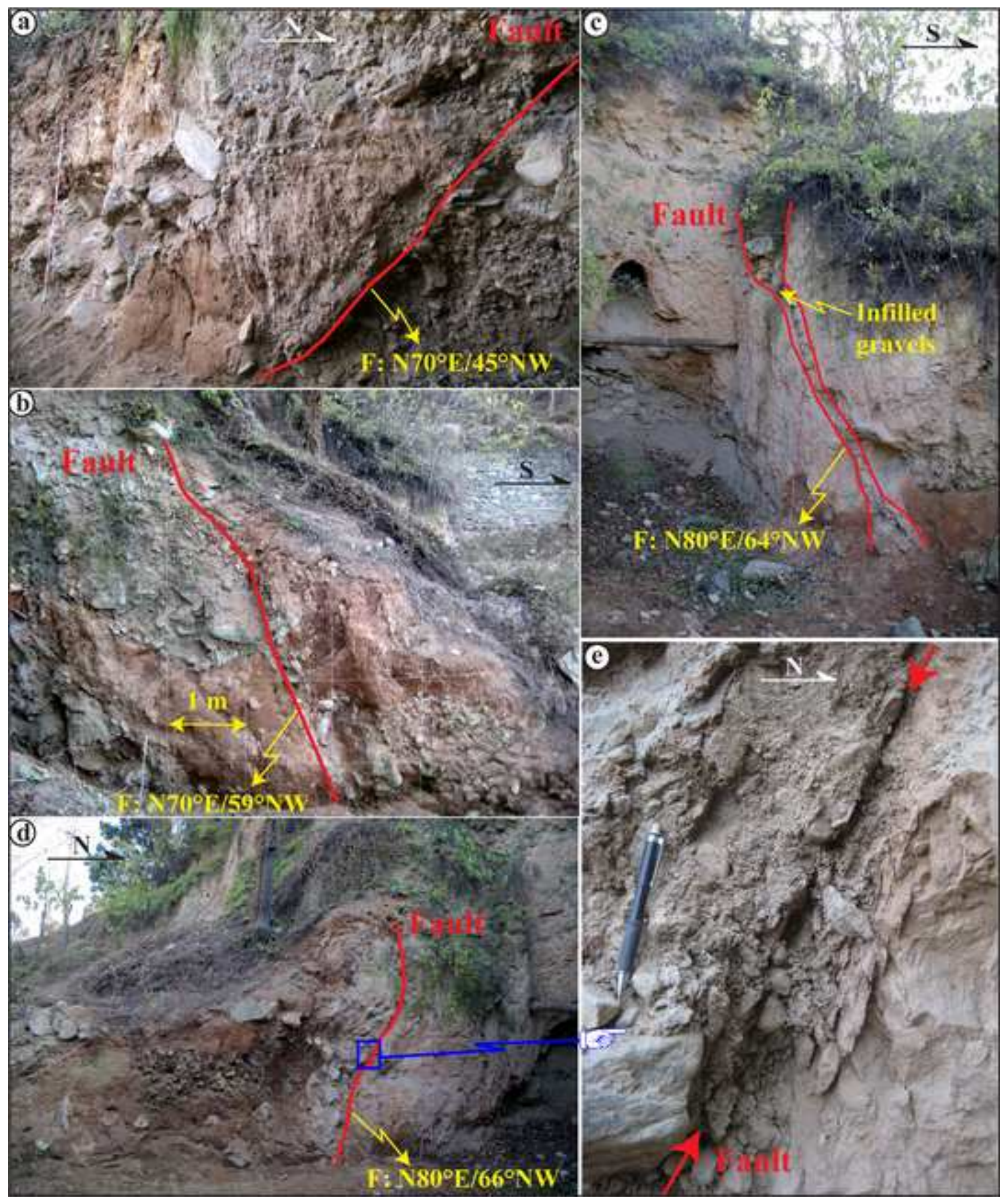




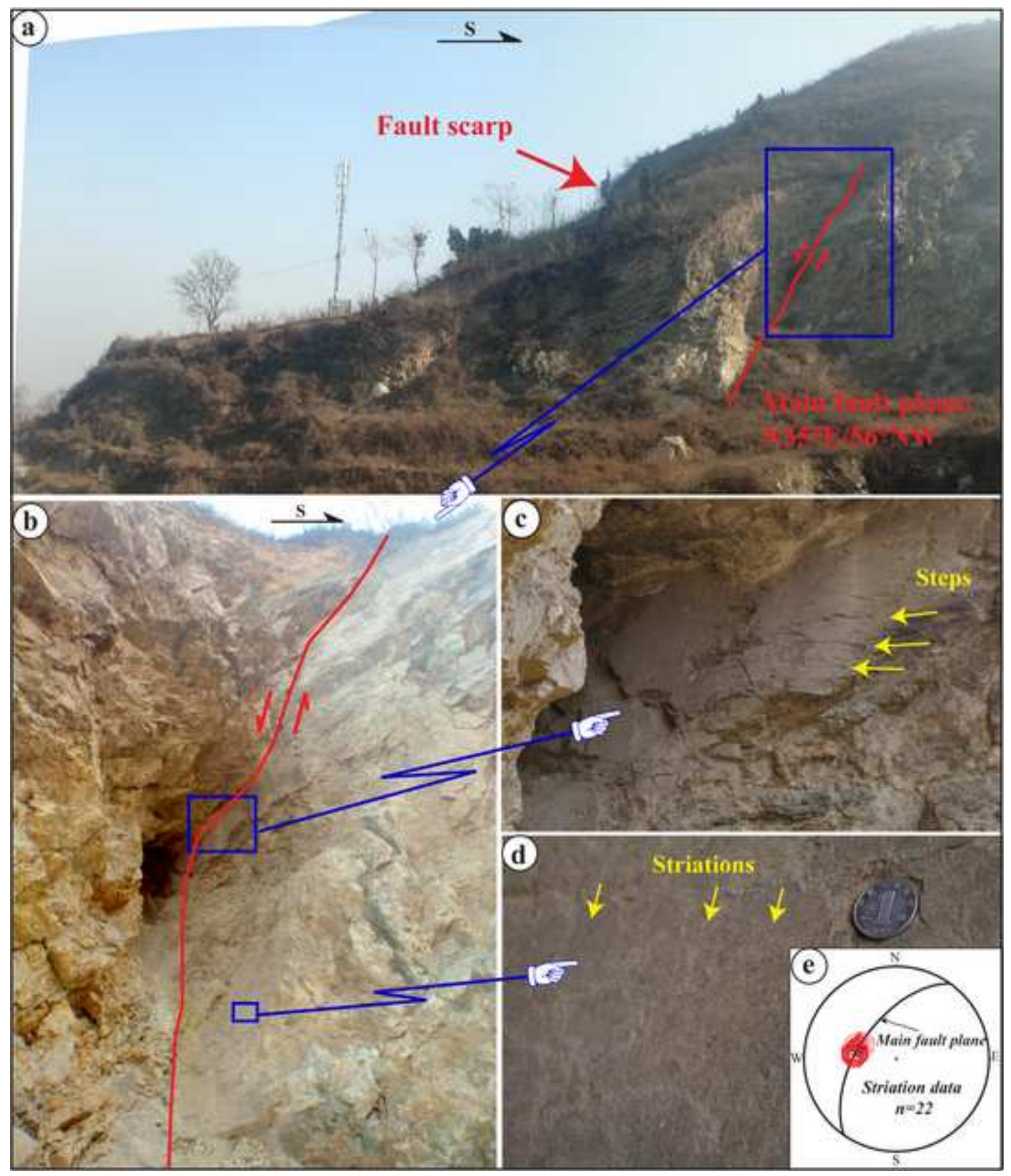


$F=$ 京部大学

(2.) 京都大学

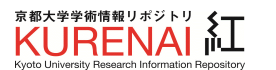

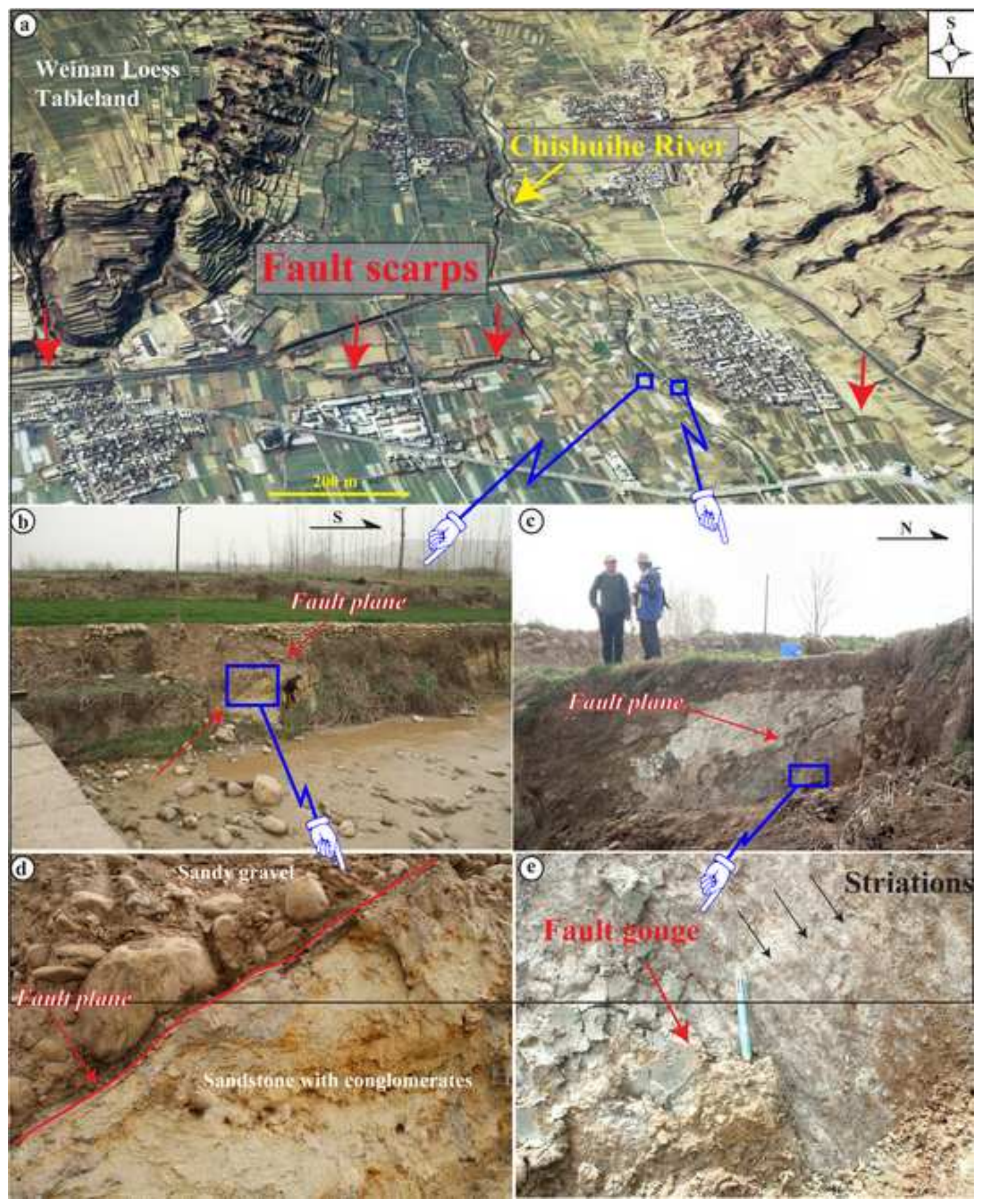




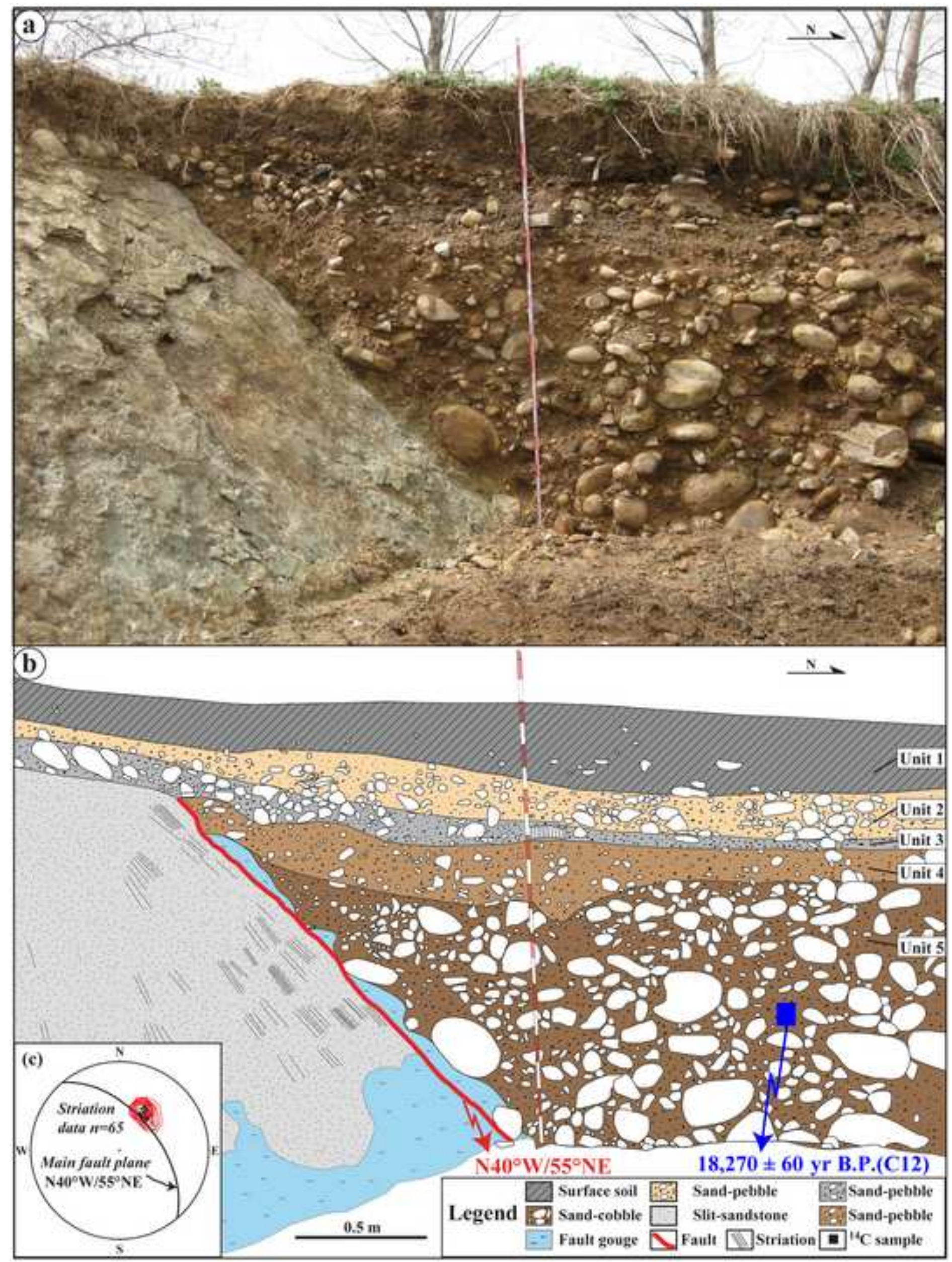


Click here to download high resolution image

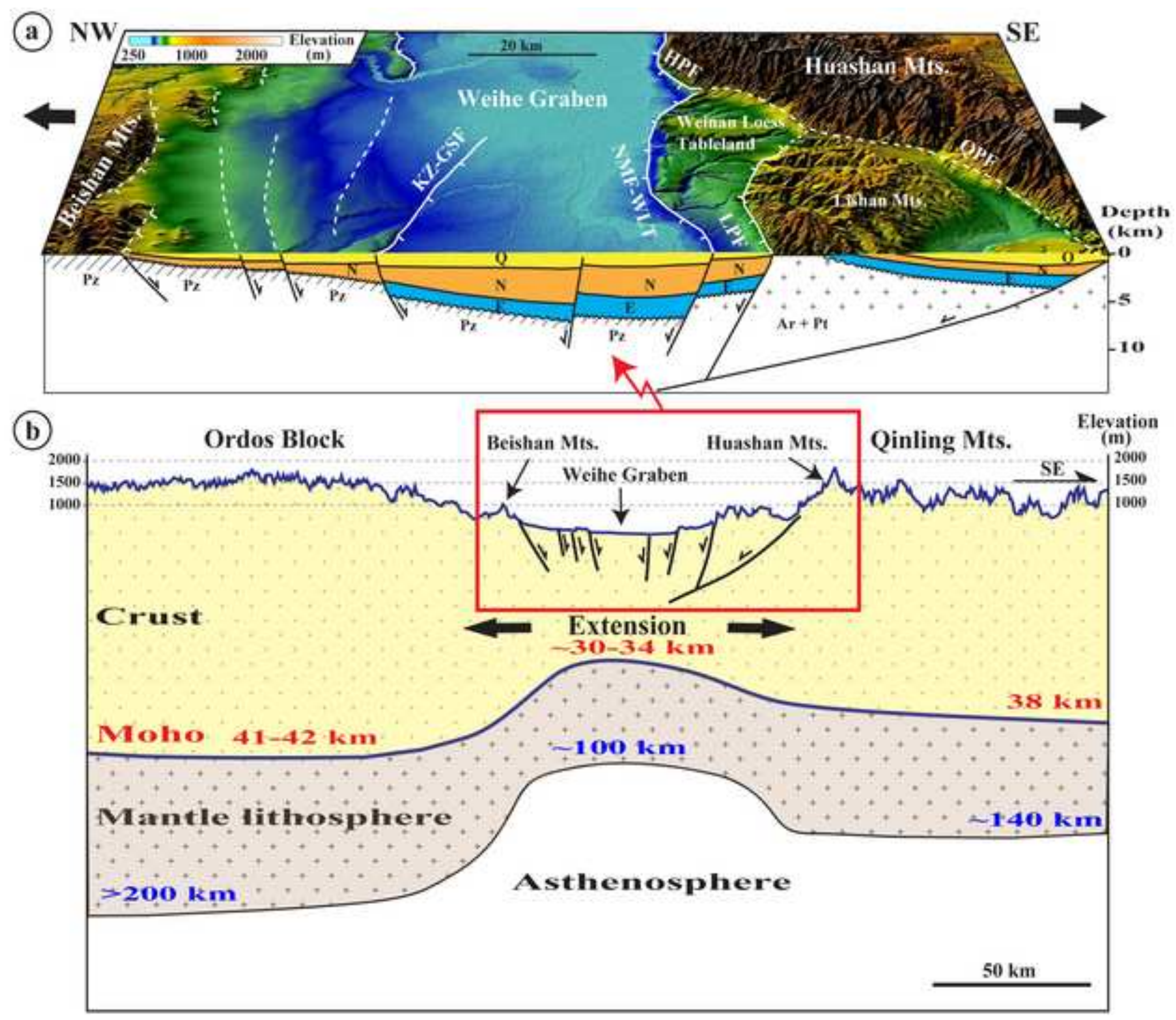

